\title{
Which infrastructures for which forest function? Analyzing multifunctionality through the social-ecological system framework
}

\author{
Mojtaba Houballah $^{1}$, Thomas Cordonnier $^{2}$ and Jean-Denis Mathias ${ }^{3}$
}

\begin{abstract}
Landscapes are subject to ecological and socioeconomic forces of change that interact in complex ways. To cope with these changes, landscape planning of natural resource management integrates sociocultural, ecological, and economic considerations in an analytic and systemic way. In this regard, social-ecological system (SES) frameworks have been developed to help analyze key factors that drive the dynamics of such complex adaptive systems. For forests, multifunctional management, which also highlights the ecological and socioeconomic roles of forests for society, has become a central objective for several European countries (e.g., France, Italy, and Germany). However, further development of methods, tools, and conceptual approaches is needed to facilitate our understanding of the arrangements behind management practices that include complex human-environment interactions. This study adopts Ostrom's SES framework and Anderies' robustness framework to highlight how forestry institutions affect forest ecosystems, forest functions, and social arrangements. As an illustration, we apply both frameworks to the Quatre-Montagnes forest, located in the south-east of France, in which multifunctionality is a major objective of forest governance. We first apply the SES framework to construct an analysis of the Quatre-Montagnes forest, specifying the first-tier and second-tier variables. From this, we describe the importance of infrastructure-related variables in shaping the interactions between components of the SES. We then apply the robustness framework, developed by Anderies, because we believe this framework enables a better analysis of ecosystem functions for infrastructure governance than the SES framework, which provides a better descriptive capacity for the variables. We discuss insights, based on our infrastructure analysis, which can be used when establishing designs for efficient forest management with heavy infrastructure dependencies.
\end{abstract}

Key Words: forest accessibility; forestry; infrastructures; multifunctionality; robustness theory; social-ecological systems

\section{INTRODUCTION}

Forests provide a large number of provisioning, regulating, supporting, and cultural functions that stabilize the climate, protect plants and animal species, provide food and shelter to local communities, protect critical human infrastructure such as settlements, roads, and railway lines from gravitational natural hazards, and isolate large amounts of carbon as a result of the recycling of gases (Nasi et al. 2002, MEA 2005, Bonan 2008, Gamfeldt et al. 2013). The ideal of maintaining a continuous flow of goods and services from the forest has occupied a central place in the field of forestry (Ciancio and Nocentini 1997, Puettmann et al. 2009). At the same time, there is increasing awareness that managed ecosystems are characterized by complex dynamics with high uncertainty related to rapid environmental and socioeconomic changes (Benson and Craig 2014). Forestry is facing a challenge that consists of achieving sustainability in a changing environment with a better integration of the interaction between ecological and social systems (von Detten 2011).

Analyzing interactions between ecological and socioeconomic components of forest ecosystems and the consequences on their integrity calls for a multidisciplinary framework that can provide a common language to understand the emergent patterns of interactions (Liu et al. 2007, Ostrom et al. 2007, and Ostrom 2009). Ostrom's social-ecological system (SES) framework (Ostrom 2009, McGinnis and Ostrom 2014) is useful for such analysis because it was designed to be applied to different SESs ranging from lakes (Brock and Carpenter 2007) and irrigation systems (Cox 2014) to fisheries (Schlüter et al. 2014, Partelow and Winkler 2016, Partelow et al. 2018) to forests (Nagendra 2007,
Fleischman et al. 2010, Oberlack et al. 2015, Vogt et al. 2015). Additionally, recent examples show that societal preferences and values can change remarkably in a relatively short period, completely changing the social environment for forest management (Johnson and Swanson 2009, Seidl and Lexer 2013). Adaptation strategies to the changing uses and values of forests need to be implemented to sustain the provisioning of multiple forest functions under changing future conditions (Spiecker 2003, Koskela et al. 2007). In this context, forests are complex SESs requiring adaptive and multifunctional management.

Multifunctional forest management that also highlights the ecological and economic roles of forest ecosystems for society has become a central objective for several European countries (e.g., France, Italy, and Germany; Slee 2012). In this regard, multifunctional forest management is defined as a land-use strategy capable of meeting divergent societal interests, supporting forestry practices adaptable to different social groups, and remaining consistent with the principles of sustainable development (Schmithüsen 2007). Nocentini et al. (2017) argued that such management was first based on "wake theory," which states that if forests are efficiently managed for wood production, then all other forest utilities will follow (Kennedy and Koch 2004). The dynamics and interactions from other ecological and social systems tended to be underestimated, often with ensuing conflicts (e.g., between timber production, landscape and nature conservation, and recreation; Mckercher 1992, Steinhäußer et al. 2015). When considering forests as complex adaptive systems (Messier et al. 2013) with multiple economic and social components, the concept of multifunctionality changes from a

${ }^{1}$ Université Clermont Auvergne, Irstea, UR LISC, Centre de Clermont-Ferrand, Aubière, France, ${ }^{2}$ Université Grenoble Alpes, INRAE, LESSEM, F-38000, Grenoble, France, ${ }^{3}$ Université Clermont Auvergne, INRAE, UR LISC, F-63178 Aubière, France 
set of different outputs to a set of complex interactions (Nocentini et al. 2017). Therefore, and for better integration of multifunctional forest management, there is a need to systematically understand the interactions between the social and the ecological systems in the forest. In this context, multifunctionality can be embedded in the SES framework, in which it can help provide a list of multitiered social and ecological variables that can generally be applied to describe variables in a complex system and across cases.

The relationship between multifunctional forest use and the capacity for forest production is highlighted with the concept of infrastructures (Bizikova et al. 2012, Yu et al. 2015). Understanding how such infrastructures mediate the interaction between human functions in the natural environment helps to tackle questions of management application and consequently to improve forest sustainability. In view of this, infrastructures are broadly defined to include natural and human-made infrastructures (both physical and social) that enable society to operate. With this in mind, the commonly used term "socialecological systems" typically emphasizes the interaction between a set of infrastructures related to social and ecological processes (Frischmann 2007, 2012, Anderies et al. 2016). Social-ecological systems, such as forests, often exhibit nonlinear dynamics because the rules of local interaction change over time (Levin 1998). Humans act alone on components of the system, attempting to adapt, to change, or to transform the system when existing interactions can no longer be supported by its components (Walker et al. 2004). Following an analysis of the relevant variables in the case study with the SES framework, we use Anderies' et al. (2004) robustness framework to conduct an institutional analysis examining how dimensions of governance and social organizations influence, adapt to, and change the interdependencies between the social and ecological variables described. Ideally, the framework can be used to provide a systematic way of thinking that focuses on how infrastructures interact in terms of the functions they provide.

We investigate how multifunctional forest management can be framed and analyzed by understanding the functionality of the forest SES. In particular, we present a novel perspective on infrastructures that explains how different infrastructures of the SES interact to produce diverse functions for the forest. To this end, we use the descriptive power of Ostrom's SES framework (Ostrom 2009, McGinnis and Ostrom 2014) to identify general variables of the system and their interactions without specifically referring to their consequences on collective action theory; we then apply it to a case study of a mountain forest (QuatreMontagnes forest, Vercors region, France). Particular to the case study, infrastructures play an important role in mediating how different parts of the system interact. For example, forest managers' exploitation of timber is limited by their use of public infrastructures (roads). Consequently, we connect variables from the SES framework analysis to their relative infrastructures. Finally, we use the robustness framework as a tool to understand the connection between the underpinned infrastructures. We present multiple forest functions through the lens of the framework by applying it to each function. We combine and use the two frameworks mentioned (SES and robustness frameworks), with a complimentary application, to explain the institutional arrangement behind multifunctional management practice. This presentation of the robustness framework application conceptually highlights the link between interactions (I) and outcomes $(\mathrm{O})$ within the SES framework variables (that will be introduced later). Indeed, we are certainly not the first to think in terms of connecting two approaches to study, analyze, and understand the complexities of SESs; for example, Partelow and Winkler (2016) interlinked the SES framework with the ecosystem services approach by applying them to the same case study, while Ban et al. (2015) associated concepts of ecosystem services, goods, and property rights with the SES framework.

Insight into the framework's application provides a more conceptually integrated view of the forest functions by connecting them through social and physical infrastructures. As a result, when viewing each function from the lens of the robustness framework, along with outlining related infrastructures and keeping in mind that there are common infrastructures for different functions, a systematic link can be identified between the concept of multifunctional forest management and the multifunctionality of different types of infrastructures. Application of the proposed framework not only allows us to highlight interactions and conflicts between forest functions, but also helps address them by identifying the infrastructures that underpin these interactions. Our ultimate goal is to address three key issues: (1) to characterize the functional system, (2) to describe the governance (infrastructure providers) linked to multifunctional forest management, and (3) to provide a conceptual approach that illustrates the multiple-tier effect of investments in infrastructures (including effects on forest functions).

\section{CASE STUDY}

The Vercors Regional Natural Park (VRNP) is a 206,000 ha area located on the border between the northern and southern French Alps (Fig. 1). Forestland dominates 139,000 ha of the VRNP, with altitudes varying from $180 \mathrm{~m}$ to $2453 \mathrm{~m}$. The main tree species are silver fir (Abies alba), European beech (Fagus sylvatica), and Norway spruce (Picea abies), particularly present in the QuatreMontagnes area. A mosaic of stand types with different tree sizes and varying species richness is now present. At low elevations, the forests are dominated by old simple coppice or mixed coppice and high forest and are generally composed of broadleaved species and silver fir standards. These forests have been mostly shaped by the heterogeneous mountain topography and a long history of human intervention. During the 19th century, almost all forests were intensively exploited for firewood, which favored beech coppices. Since the early 20th century, they have been progressively converted into mixed high forests, sometimes through conifer plantation but often by natural regeneration of local coniferous species. Approximately half of these forests are public (Gonzales-Redin et al. 2016) and the rest are in the hands of private stakeholders. The particular case study selected for this research focuses on 25,000 ha (12\% of the total area) located at the north of the VRNP, in an area known as Quatre-Montagnes. Figure 1 shows the Quatre-Montagnes region within the Regional Natural Park (PNR) in the French Alps, (in dark green, public forests). The area is part of the Grenoble agglomeration with implications for the impact of tourism.

In accordance with the principles of preserving biodiversity and reducing gas emissions (adapted from the Earth Summit in Rio de Janeiro 1992), the law on forest orientation (2001) recognized 
Fig. 1. Study area location in the Alpine Mountain Range and the site of Quatre-Montagnes (green area) at the north of Vercors Regional Park (VRNP), French Alps (Partelow 2016). Panel (a) represents the location of the Alpine massif in the European continent. Panel (b) represents the Vercors Regional Park (VRNP) location in the Alpine massif. Panel (c) represents the location of the study area site Quatre-Montagnes (green area) as well as nonforested (white) and forested (light gray) areas inside the Vercors. Moreover, panel (c) also shows public forest areas within the Vercors' mountains (dark gray).

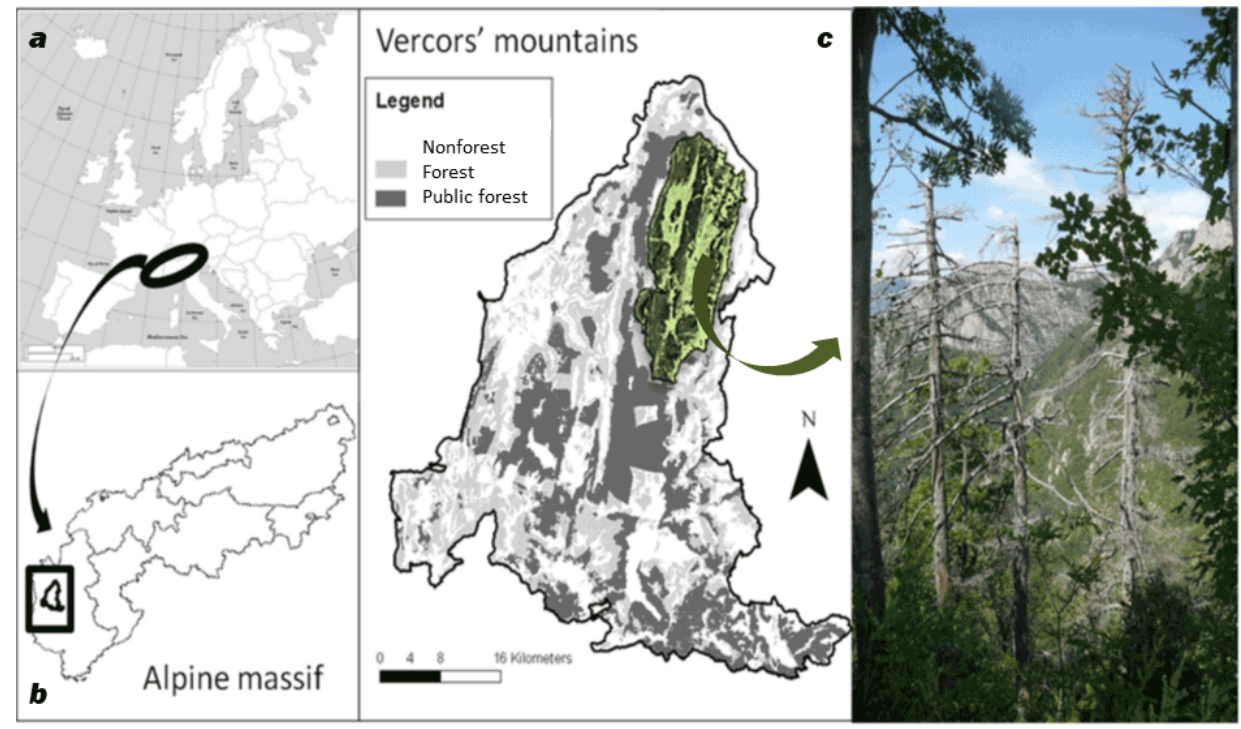

the multifunctionality of the forest. Alpine countries support the contribution of the forest to the sustainable development of their territory (Onida 2009, Avocat et al. 2012). The general environment forum and the council of forests led to the adoption of a protocol of understanding among forest managers: to produce more wood while still preserving biodiversity by favoring a territorial approach concerted in the framework of multifunctional forest management. In the Vercors, nature conservation plays an important role and even though multifunctionality is considered essential for wood production, biodiversity and recreation are being consolidated at all scales (Cordonnier et al. 2014, Sarvašová et al. 2014, Bugmann et al. 2017; cf. http://www.arange-project.eu/). Moreover, the nature of the topography and the landscape of the forest represent an obstacle because $36 \%$ of the forest is inaccessible and not exploitable for timber users (Cordonnier et al. 2014).

Forest governance in the Vercors comprises three levels (see Fig. 2): the region, departments, and communes. The region develops its own strategy and supports territorial projects, e.g., the regional strategy for economic development and innovation (SRDEI) and sustainable development contracts with territory projects (CDDRA), with the objective of mobilizing wood in the area and limiting gas emissions. The departments aim to reinforce the rural/ urban environment by developing their own strategies and supporting territorial projects, e.g., developing agriculture strategic plans. The communes, considered owners of public forests, promote wood production in the area and, in addition, lay grounds for the forest territory charters (Chartes Forestiers de Territoire, CFT in French) and execute operational processes according to the different guidance documents that impact the territory. Specifically, the CFT represents a new flexible structure of local governance specific to France. The charters were introduced by the law on forest orientation (Ministère de l'Agriculture et de la Pêche 2001) as an instrument of sustainable development of rural territories through the inclusion of the advantages offered by forests into their economic, social, and cultural environment and through the multifunctionality of forests. Based on stakeholders' participation, CFT is entirely aligned with governance implementing participatory mechanisms, decentralization, and empowerment of regional and local government, increasing the role of local communities, and promoting secure land-tenure arrangements (KouplevatskayaButtoud 2009). Aligning itself with the European priorities, the CFT's aim is to integrate the forest as a core territorial policy together with other major issues such as the development of tourism and water management.

\section{DATA COLLECTION AND ASSESSMENT}

An analysis was performed of the studies and literature produced by the ARANGE and the Cordonnier et al. (2014) projects, which focused extensively on social, economic, and ecological data extraction of several case studies across Europe, for comparison with the case studies found in the ARANGE project. This detailed analysis is based on the identification of information that is closely related to SES framework variables. Moreover, a systematic review of peer-reviewed literature was conducted based on scholarly records from the Scopus database. Searches were performed (as of January 2017) to find literature directly related to the Quatre-Montagnes forest. In particular, we focused our search on literature concerning the performance of functions (wood production, tourism, and nature conservation), important 
Fig. 2. Schema representing the different entities involved in the governance of the forest. Orange rectangle represents the Vercors regional natural park (PNR) where it is partly governed by three entities. Regional governance, which is represented by a green circle and its administration occupy all the PNR. Departmental governance represented by a light blue square where the jurisdiction resides almost on all the PNR. Communal governance represented by a pink rectangle inside the PNR. Although the jurisdiction overlaps, the three entities share different objectives and authority in the Vercors.

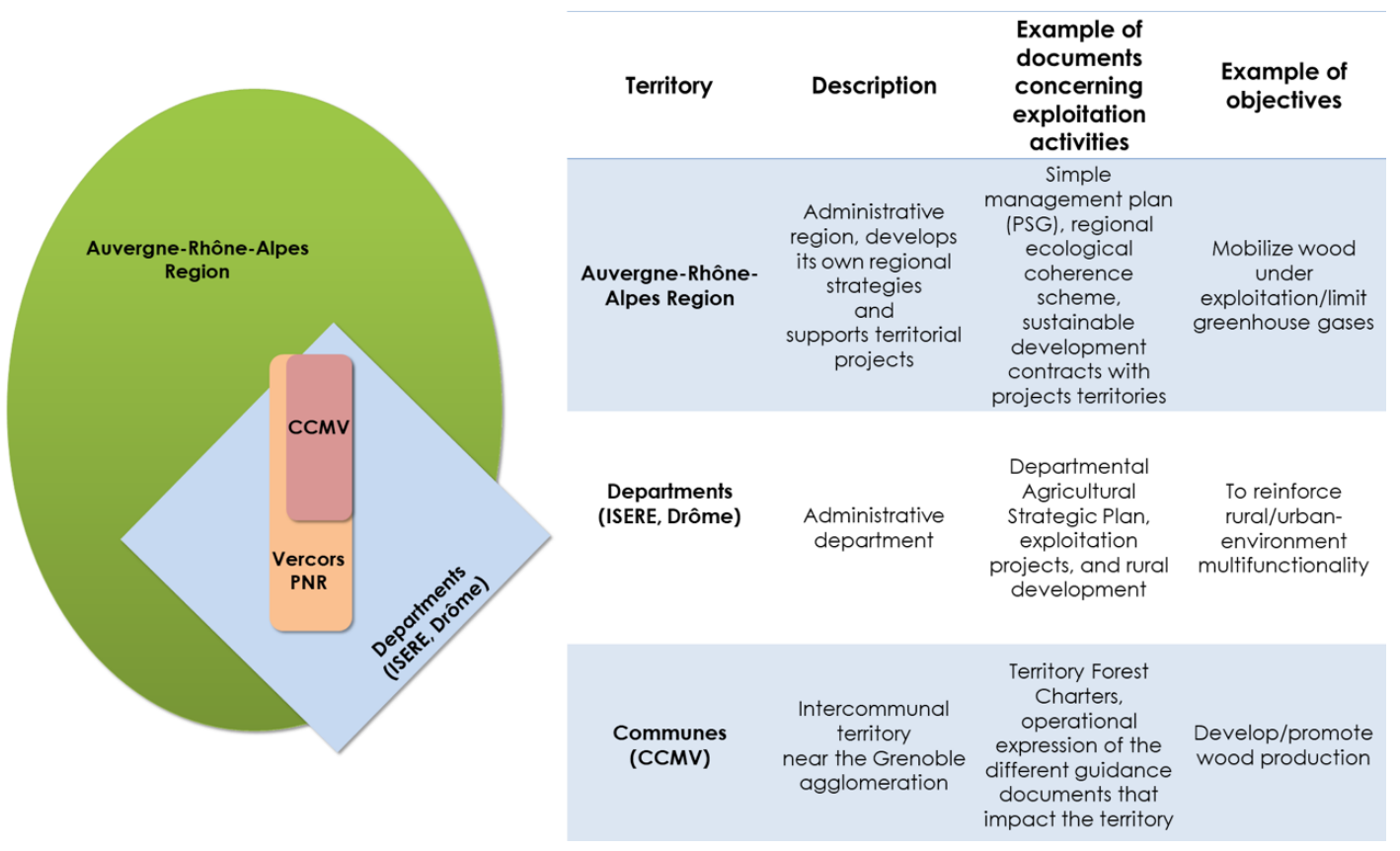

stakeholders' conflicts, and problems linked to these conflicts. Search strings were guided by an extensive list of search terms (English and French terms) related to wood production, tourism, nature conservation, and conflicts, with all terms tied to QuatreMontagnes forest and Vercors forest. In addition to the literature from the projects (ARANGE, Cordonnier et al. 2014), the search yielded a total of 15 articles and reports (Appendix 1, Table S1). Each article and report were read, evaluated, and coded with standardized criteria by the authors. Consensus coding was reached on the following categories for each article: source, type of study, year of publication, and tone of the assessment. Data assessment was made according to the language that was most relevant for each variable, in which importance was qualitatively estimated on three levels: strong, moderate, and low. This estimation was made in comparison with other European mountain forests assessed by the ARANGE project. For a detailed explanation of the method used for data collection and assessment, we refer the reader to Appendix 1.

\section{SOCIAL-ECOLOGICAL SERVICES FRAMEWORK ANALYSIS}

The SES framework (Ostrom 2009, McGinnis and Ostrom 2014) identifies the broad characteristics of the resource system and related resource units, governance systems, and actors that together affect the structure of action situations leading to interactions and outcomes, as well as being embedded in social, economic, and political settings, and with related ecosystems (see
Fig. 3; Hinkel et al. 2014). Within each of these broad characteristics, there are second-tier variables, and frequently, third-, fourth-, and fifth-tier variables. This proposed nested hierarchy of variables was not intended to suggest that all the variables are relevant for all the cases. Rather, analysts might find the SES framework helpful as a diagnostic tool that enables them to clearly define variables of interest and organize them into connected groups (McGinnis and Ostrom 2014). However, in this article, and according to the required level of study and analysis, we will limit our forest system characterization to the first- and second-tier variables (Fig. 3).

\section{Resource system and resource units}

The Quatre-Montagnes SES (Fig. 3) can be characterized according to the forest as a resource system. The forest cover is approximately 17,000 ha and is labeled as public (owned by communes; $60 \%)$ and private $(40 \%)$. The area contains numerous human-constructed facilities related to tourism (accommodation, restaurants, sports and leisure, etc.), timber industry (side road wood deposition areas, etc.), or both (i.e., roads; Achard 2011). Changing socioeconomic factors have led to a suite of land-use changes in the forested areas, and significant changes in the provision of some ecosystem functions (Gonzales-Redin et al. 2016). For example, using the forest as an obstacle against rockfall, conservation of the ecosystem (a forest reserve is the study area), developing tourism (e.g., ski resorts, green tourism), timber harvest, and many other functions. 
Fig. 3. The modified SES framework for the Quatre-Montagnes case study. Solid boxes denote first-tier categories; resource systems, governance systems, resource units, and actors are the highest-tier variables (they contain multiple variables at the lower tiers). All the actions take place as inputs and transform into outcomes in the action situations. Dashed arrows denote feedback from the action situations to each of the top-tier categories. Exogenous influences from related ecological systems or social-economic-political settings can affect any component of the SES. We only outlined variables that we found relevant to our case study through our identification method. For a more detailed view on the data and assessment method, see Appendix 1.

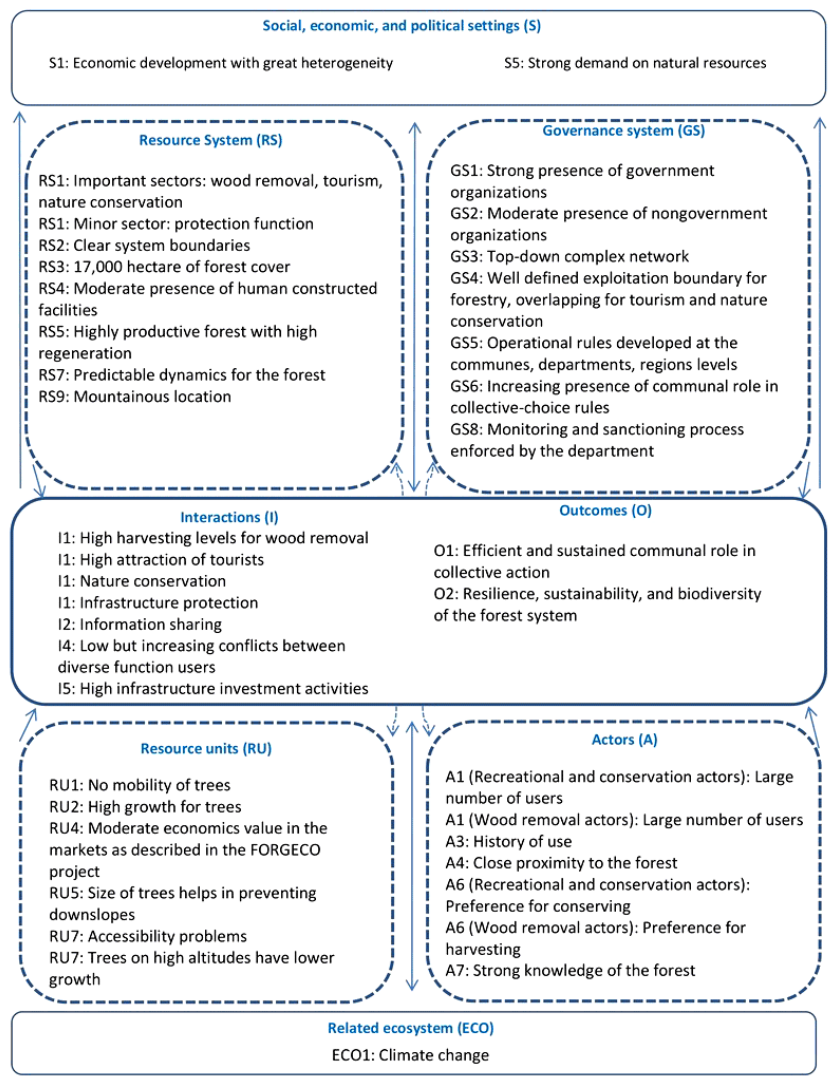

Keeping in mind that the forest is generative in terms of wood production, tourism is also considered a major industry in the area because of the mountainous terrain. Nevertheless, within the VRNP, the forest is widely viewed as "nature preservation" or "landscape esthetic" (Tenerelli et al. 2016), which, along with winter tourism, is the main engine for the local tourism. However, the area is widely exploited for timber in both public and private forests. Consequently, conflicts exist between different actors of the timber and tourism industry, and the objective of the current forest management entails a strategy to "produce more while protecting better" (Achard 2011). Within the forest, there are diverse species of trees such as silver fir, Norway spruce, and European beech, rendering its economic value high, but owing to topographic obstacles, the timber industry faces particular difficulties in mobilizing resources (Avocat et al. 2012). Consequently, some parts of the Quatre-Montagnes forest are underexploited (Puech 2009), which leads to the aging of these stands and, eventually, to the degradation of the wood production aspect.

\section{Actors and governance system}

Private forests

Since 1963, forest owners have been required by law to create a statutory document called "Plan Simple de Gestion" (PSG) to be validated by the regional centers of forest property (CRPFs). This document is described in the forestry code and integrated into the sustainable management policy of French forests (Tissot and Kohler 2013). The PSGs must comply with the regional woodland management schemes (SRGSs) set up by the CRPFs to define woodland management practices adapted to each region. Owners of small forests can either subscribe to a code of good forestry practices (CBPS), which makes forestry practices easier and permits them to receive subsidies from the state, or file a management regulation.

\section{Local and regional forests}

The French forestry regime implemented by the National Forestry Office (ONF) in public forests ensures the sustainable management of forest resources belonging to local and regional authorities. It is perfectly able to cope with the multiplicity of public owners and the need to combine the long-term rhythm of the forest with the short cycles of elected officials. At the national level, the rate of annual timber harvesting is less than that of annual forest growth, and thus an increase in timber harvesting has been decided through the State-ONF-FNCOFOR (National Federation of Forest-Owning Communes) contract with a view to stabilizing the wood capital (Tissot and Kohler 2013). The income derived from timber harvesting is vital for rural communes. Activities around logging generate jobs that contribute to the maintenance of the population in rural areas. In addition, public forests provide open and accessible spaces for leisure activities. Fully aware of the multifunctionality of the forest, communes have combined the CFT with the aim of proposing a conceptual framework to local stakeholders to integrate the development of forests with participatory forestry and precise objectives as well as local actions (KouplevatskayaButtoud 2009).

\section{Governance}

The bulk of the funding for governance functions comes from subsidies by the European Union (EU) supporting multifunctional and sustainable forest management (Sarvašová et al. 2014). As a central decision-making apparatus, the state has, via a mutual adaptation of priorities and positions, given the leading role in the CFT to the communes represented at the national level by the FNCOFOR. However, according to France's decentralized forestry regime, the governance functions are shared by three different organizations (communes, departments, and region; see Fig. 2). First, municipalities are considered owners of public forest and they act on the forest through the ONF to prepare management plans and to exploit the communal areas following regional and national recommendations for biodiversity and environmental preservation. In addition to setting up the rules-in-use of public infrastructures, municipalities 
invest (with subsidies from the EU) in infrastructures for the enhancement of user-forest interactions. Second, the department is responsible for sanctioning and monitoring as well as establishing sensible areas to protect biodiversity. Additionally, departments receive subsidies by the EU to construct roads to enhance accessibility to the forest and facilitate timber mobilization in the area. Third, the objectives of the regional organizations consist in mobilizing timber for exploitation and deploying snow canons as an artificial technique to assist in winter tourism. On the one hand, all forests belonging to municipalities or public organizations are considered to be public utilities and are therefore managed according to the French forestry regime, in which forests are under strict management planning. This management has to integrate the multifunctionality of the forest and not only wood production. On the other hand, the PSG document is described in the forestry code and integrated into the sustainable management policy of French forests. The regional strategic documents of sustainable forest management are all approved by the state for public forests as well as for private forests. The composition of regional commissions reflects the diversity of the actors involved in forestry at the regional level (Tissot and Koehler 2013).

\section{Key elements and conclusions of the social-ecological systems analysis}

\section{Tourism and nature conservation}

Forests are a very important part of the landscape, especially in the Vercors area. Many outdoor recreational activities can be undertaken in a forested area. However, the mere existence of forests in the area may not be enough to promote tourism, and therefore other activities, services, and infrastructures are also required. Moreover, nature conservation is an important function of the forest, contributing to an increase in forested areas and enhancing the ecology of the forest and its sustainability. Although these two goals frequently reinforce each other, sometimes pursuing both simultaneously can result in conflicts (Lafond et al. 2017). In some cases, recreational use can severely degrade an area such that not only the environment is spoiled, but also the quality of the recreational experience itself is diminished (Cole 1993). Closure of the landscape can be detrimental to scenic beauty, and thus to recreational activities (Dunford et al. 2018). The SES framework analysis indicates that in sites in which tourism has been promoted, for instance, through the establishment of protected areas, there are apparent economic benefits for the local population. However, tourist activity in natural areas needs to be managed carefully and it should be planned and organized in advance to maximize the benefits for locals while enhancing nature conservation at the same time.

\section{Forestry}

As mentioned earlier, the Quatre-Montagnes forest varies greatly in terms of tree species, productivity, major roles, and ownership. Forest cover is increasing in the area (European Observatory of Mountain Forests 2000). Furthermore, with its contribution to tourism, the forest plays a significant role in the economy of the area by providing employment, maintenance, harvesting, and fuelwood. Moreover, wood production and fuelwood production are considered the most important aspect of the QuatreMontagnes forest. Nevertheless, to meet the demands placed on the forest, exploitation has to increase (Tissot and Koehler 2013).
Certain behavioral reluctances are added to technical and economic difficulties; the topography represents another obstacle, which has an effect on the price of timber. The number of forest holders using skidders has decreased, and $62 \%$ of the Rhone-Alps forest area is considered difficult to exploit (Avocat et al. 2012).

\section{Road infrastructures}

The National Forestry Fund (FFN) had a strong impact on the environment and the economy in the area. It led to a rapid increase of the forested area and allowed for the creation of infrastructure (i.e., roads and tracks) that made logging easier and more efficient (Tissot and Koehler 2013). Nevertheless, being a mountain forest and owing to its topology, infrastructure provision (forest roads) in the Quatre-Montagnes area is generally perceived as being scarcer and of poorer quality than in other parts of Europe. For example, Cordonnier et al. (2014) showed, via digital terrain models, that $36 \%$ of the forested area in the Quatre-Montagnes is currently inaccessible and thus not exploited efficiently. Evidently, the area is lagging behind and faces difficulties related to lack of accessibility, which restricts both forest and recreation industries (Nordic Centre for Spatial Development 2004). Reduced accessibility is consequently the most unanimously recognized drawback of the Quatre-Montagnes forest compared with other forested areas across Europe.

The development of wood exploitation in the Quatre-Montagnes area refers to the way resources may be appropriated in a highly heterogeneous area. The economic and logistic construction of the wood supply chain has to deal with a constraining geographic frame (including difficulties to access resources), the multifunctionality of the mountain forests (i.e., maintaining the beauty and biodiversity of the landscape, which is essential for tourism and nature conservation functions, respectively), and the fragility of the ecosystem (Mina et al. 2017). Moreover, beyond the mobilization of technical regulations to improve the performance of the forest function (which enhances economic environmental efficiency along with forestry and recreational activities), identifying and understanding the structure the forest SES and its dynamics are prerequisites for its sustainability, and thus for the sustainability of the services it provides (e.g., forestry, tourism, etc.).

Moreover, the diverse processes initiated by timber users, on one hand, and by tourism and nature conservation users, on the other hand, have made clear the need for a common language between the different functions performed. Such a common language will have to be developed at different institutional levels, between actors having to deal with their strategies at both temporal and spatial scales.

\section{FOREST MULTIFUNCTIONALITY THROUGH THE ROBUSTNESS FRAMEWORK}

Muneepeerakul and Anderies (2017) suggested that the notion of social-ecological systems (SESs) frequently used to frame common pool resource (CPR) problems does not adequately capture important aspects of hard human-made infrastructures, which condition the interaction between social and ecological components in all SESs (i.e., spillovers; Anderies et al. 2016). Nevertheless, the importance of applying the SES framework lies in the analytical description of the case study at hand, which embraces institutional complexity by examining multiple tiers of 
variables. However, recent movements have distinguished between the applications of the SES and other frameworks. For example, McGinnis and Ostrom (2014) distinguished between the SES framework that captures the natural dynamics in SESs, and the social-ecological-technical system in which the constructed dynamic process of complex interactions is highlighted. In this context, Muneepeerakul and Anderies (2017) sought to address problems associated with the fact that the importance of infrastructure is often invisible to users until it fails. The commonly used term "social-ecological systems" typically emphasizes the interaction between a set of infrastructures related to social and ecological processes (Ramaswami et al. 2012).

We use the robustness framework (Anderies et al. 2004; Fig. 4) to analyze the dynamics of the forest SES. The framework delineates four components of the SES (resource, resource users, public infrastructures, and public infrastructure providers), their interactions, and how these components and interactions influence the capacity of an SES to cope with internal and external disturbances. As defined by Anderies et al. (2016), there are five main types of infrastructure considered in the framework: (1) hard infrastructure, i.e., human-made structures such as roads; (2) soft infrastructure, i.e., collections of human-made instructions for using other types of infrastructure such as institutional arrangements and decision-making processes; (3) natural infrastructure, i.e., hard infrastructure that is not humanmade but is critical for society (the forest); (4) human infrastructure, which refers to knowledge; and (5) social infrastructure, which refers to the relationships we have with others. The framework explicitly recognizes the role of public infrastructures in influencing the system on the component level. Public infrastructure can be either hard or soft and is typically designed to achieve certain societal output (Muneepeerakul and Anderies 2017).

Fig. 4. The conceptual model of the robustness framework as introduced by Anderies et al. (2004). It specifies four generic components common to most social-ecological systems (resource, resource users, public infrastructure, and public infrastructure providers) and their interactions (Links 1 to 6). It also describes the presence of external disturbances (Links 7 and 8). Boxes refer to biophysical components of the system whereas circles refer to social components.

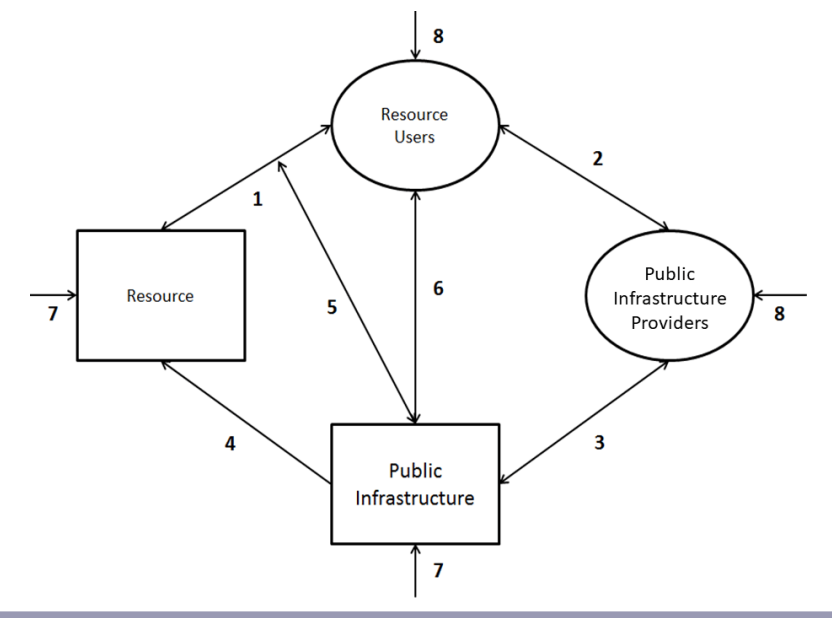

The robustness framework can be used to provide a systematic way of thinking, which focuses on how these different infrastructures interact in terms of the functions they provide, which avoids artificial and potentially misleading distinctions between various systems. Moreover, it is necessary to recognize and clarify the "configural" nature of the system, i.e., a minimal set of infrastructure classes is required before interesting higherlevel organizational patterns emerge (i.e., well-being, communities, societies, etc.). When thinking in terms of a robustness framework, the question is not "What is the right policy or set of institutions for a particular problem or context?" but, rather, "What infrastructure can we influence that might nudge the system to evolve toward a robust configuration that produces mass and information flows valued by the society?" (Anderies et al. 2016). We provide a general analysis, adopted from the SES framework analysis, of the case study through the robustness framework perspective. In particular, we use the robustness framework to provide an infrastructural point of view of some of the forest functions, and in the process, we emphasize the importance of infrastructures in contributing to the operation and development of each of the functions mentioned (Table 1).

Timber and biomass for energy functions

The forestry sector is an important provider of wood for basic human needs as well as an important employer, and it has the potential to create even more jobs in the future. Moreover, according to the Comité du massif des Alpes set up by the French national planning agency, sustainable planning of forest harvesting will have become an important issue by the year 2020, and energetic valorization will be a part of the alpine forest strategy (Avocat et al. 2012). Several planning tools (e.g., Schéma stratégique forestier du massif des Alpes and the Inter-regional Convention for the Alpine Massif) are clearly aimed at a rise in wood (e.g., fuelwood) utilization in the Vercors, if it meets the mountain specificities and their vulnerabilities. Thus, the development of the forestry sector is clearly based on an increase in wood demand (AGRESTE 2014). Table (1) shows the timber and biomass for the energy function of the forest from the standpoint of the robustness framework. Forest owners use physical and social infrastructure to help in wood production from the forest, and in the process, forest owners acquire characteristic information about the forest (Table 1, Link 1). Resource users (RU) provide money to the public infrastructure providers (PIP) in the form of taxes, which allows for its operation, and in addition, resource users elect the public infrastructure providers and pay taxes (Table 1, Link 2). The PIPs produce public infrastructure (PI), both physical and social, such as roads and forestry organizations, and, in return, information flows back (Table 1, Link 3). The PIP, through building PI, aim not only to offer a tool for enhancing wood extraction but also to enforce rules through which they can prevent overexploitation and degradation of the forest. Information about forest owners' activity flows back to the PI (Table 1, Link 5). Additionally, PI enables or restricts the actions of RUs by providing knowledge that changes the perception of RU. For example, the change to multifunctional forest management because of a better perception of knowledge (Table 1, Link 6).

Tourism function

As discussed earlier, the tourism industry and the presence of large numbers of tourists have played an important role in the 
Table 1. Forest functions from the point of view of the robustness framework and infrastructures. The table also shows the placement of the relevant social-ecological systems (SES) variables associated with components of the framework. The "+" measurements signify the importance of the types of infrastructure to the functionality of their relevant infrastructure (see Appendix 1 for more information on the measurements). See Figure 3 for explanation of codes (e.g., A1, GS1, RS1, etc.). Note: PIP = Public Infrastructure Providers; PI = Public Infrastructure; PNR = Parc Naturel Régional; DDT = Direction Départementale des Territoires; ONF $=$ Office Nationale des Forêts; CCMV = Communauté de Communes du Massif du Vercors; RU = Resource users; TVA = Taxe sur la valeur ajoutée (tax on the added value).

\begin{tabular}{|c|c|c|c|c|}
\hline & & Functions & & \\
\hline \multicolumn{5}{|l|}{ Robustness framework } \\
\hline Forest (RS3) & $\begin{array}{l}\text { Timber production/ biomass } \\
\text { for energy production (RS1) }\end{array}$ & Tourism (RS1) & Protection (RS1) & Nature conservation (RS1) \\
\hline User activity & $\operatorname{High}(\mathrm{A} 1, \mathrm{~A} 3, \mathrm{~A} 4, \mathrm{I} 1)$ & High (A1, A3, A4, I1) & Low & High (A1, A3, A4) \\
\hline Users & $\begin{array}{l}\text { Forest owners, and } \\
\text { communes (A1) }\end{array}$ & Tourists, ski companies (A1) & Tourist, foresters (A1) & Conservationist (A1) \\
\hline PIP & \multicolumn{4}{|c|}{ Municipals, departments, regions (GS1, GS3, GS5, GS6) } \\
\hline PI & $\begin{array}{l}\text { Roads, sawmills, ONF, DDT, } \\
\text { CCMV, etc. (GS1, GS2, RS4) }\end{array}$ & $\begin{array}{l}\text { Roads, PNR, CCMV, } \\
\text { restaurants, ski centers, etc. } \\
(\mathrm{GS} 1, \mathrm{GS} 2, \mathrm{RS} 4)\end{array}$ & none & $\begin{array}{c}\text { PNR, DDT, CCMV, protected } \\
\text { areas, etc. } \\
\text { (RS4) }\end{array}$ \\
\hline $\begin{array}{c}\text { Link 1 } \\
\text { (U↔Forest) }\end{array}$ & $\begin{array}{c}\text { Timber exploitation (A6, } \\
\text { RS2, RS5, RU2, RU4, I1, } \\
\text { O2) }\end{array}$ & $\begin{array}{c}\text { Cultural services (A6, RS2, } \\
\text { RS9, I1, O2) }\end{array}$ & $\begin{array}{l}\text { Infrastructure protection (I1, } \\
\text { O2) }\end{array}$ & $\begin{array}{c}\text { Conservation of natural } \\
\text { infrastructure (A6, I1, O2) }\end{array}$ \\
\hline $\begin{array}{c}\text { Link } 2 \\
(\mathrm{U} \leftrightarrow \mathrm{PIP})\end{array}$ & Elections and taxes (GS6) & $\begin{array}{c}\text { Elections, TVA, and license } \\
\text { fees (GS6) }\end{array}$ & none & Elections (GS6) \\
\hline $\begin{array}{c}\text { Link } 3 \\
(\mathrm{PIP} \leftrightarrow \mathrm{PI})\end{array}$ & $\begin{array}{l}\text { Provisioning of forest roads } \\
\text { and forestry institutions } \\
\text { (RS4, I5) }\end{array}$ & $\begin{array}{l}\text { Provisioning of accessibility, } \\
\text { rangers, accommodations, } \\
\text { etc. (RS4, I5) }\end{array}$ & $\begin{array}{c}\text { Provisioning of natural } \\
\text { infrastructure through tree } \\
\text { planting }(\mathrm{RS} 4, \mathrm{I} 5)\end{array}$ & $\begin{array}{c}\text { Provisioning of forest } \\
\text { regulations and nature } \\
\text { conservation institutions (RS4, } \\
\text { I5) }\end{array}$ \\
\hline $\begin{array}{c}\text { Link } 4 \\
(\mathrm{PI} \leftrightarrow \text { Forest })\end{array}$ & none & none & none & none \\
\hline $\begin{array}{c}\text { Link } 5 \\
(\mathrm{PI} \leftrightarrow \operatorname{Link} 1)\end{array}$ & $\begin{array}{l}\text { Harvesting and regulations } \\
\text { for preventing damages to } \\
\text { the forest (GS5, GS8, RU7, } \\
\text { I1, S5) }\end{array}$ & $\begin{array}{l}\text { Regulations for limiting the } \\
\text { effect on the forest ecosystem } \\
\text { (GS4, GS5, GS8, RU7, I1, } \\
\text { S5) }\end{array}$ & none & $\begin{array}{c}\text { Enhancement or restriction of } \\
\text { the effort for conservation } \\
\text { (GS4, GS5, GS8, RU7, S5) }\end{array}$ \\
\hline $\begin{array}{l}\text { Link } 6 \\
(\mathrm{PI} \leftrightarrow \mathrm{U})\end{array}$ & $\begin{array}{c}\text { Guarantying sustainable } \\
\text { forest management (RS7, } \\
\text { GS4, RU4, RU7, I2, I4, O1) }\end{array}$ & $\begin{array}{l}\text { Constraining the access to } \\
\text { the forest to avoid conflicts } \\
\text { and limit negative } \\
\text { environment impacts (RU7, } \\
\text { A7, I2, I4, O1) }\end{array}$ & none & $\begin{array}{l}\text { Increasing nature conservation } \\
\text { activities through regulating } \\
\text { forest management practices } \\
\text { and monitoring (RU7, A7, I2, } \\
\text { I4, O1) }\end{array}$ \\
\hline $\begin{array}{c}\text { Link } 7 \\
\text { (exogenous variables } \\
\text { affecting natural and human- } \\
\text { made infrastructure) }\end{array}$ & $\begin{array}{l}\text { Climate change (affects tree } \\
\text { growth, survival, and } \\
\text { regeneration, ECO1) }\end{array}$ & $\begin{array}{c}\text { Climate change (affects ski } \\
\text { tourism and related activities, } \\
\text { ECO1) }\end{array}$ & $\begin{array}{c}\text { Climate change (more fires or } \\
\text { insects inducing secondary } \\
\text { natural hazards, ECO1) }\end{array}$ & $\begin{array}{c}\text { Climate change (affects the } \\
\text { biodiversity and forest } \\
\text { ecosystems, ECO1) }\end{array}$ \\
\hline $\begin{array}{c}\text { Link } 8 \\
\text { (exogenous variables } \\
\text { affecting social } \\
\text { infrastructure) }\end{array}$ & Market variability $(\mathrm{S} 1, \mathrm{~S} 5)$ & Strong demand $(\mathrm{S} 1, \mathrm{~S} 5)$ & none & Social incentive (S5) \\
\hline \multicolumn{5}{|l|}{ Infrastructures } \\
\hline Soft-human made & $\stackrel{+}{\stackrel{+}{(D D T} \mathrm{ONF} \text { CCMV etc) }}$ & $\begin{array}{c}++ \\
(\mathrm{PNR} \text { CCMV etc })\end{array}$ & $\begin{array}{c}+ \\
(\mathrm{ONF})\end{array}$ & $\begin{array}{c}+++ \\
(\text { PNR DDT CCMV etc) }\end{array}$ \\
\hline Hard-human made & $\begin{array}{c}\text { (DD }, \text { ONF, CCMv, etc.) } \\
+++ \\
\text { (Roads, sawmills, etc.) }\end{array}$ & $\begin{array}{c}\text { (Restaurants, ski centers, } \\
\text { roads, etc.) }\end{array}$ & $\begin{array}{c}(\mathrm{ONF}) \\
+ \\
\text { (None) }\end{array}$ & $\begin{array}{c}+ \\
(\text { None })\end{array}$ \\
\hline Human & $\begin{array}{c}++ \\
\text { (Forest owners) }\end{array}$ & $\begin{array}{c}+++ \\
\text { (Tourists and business men) }\end{array}$ & $\begin{array}{c}+ \\
\text { (Tourists and foresters) }\end{array}$ & $\begin{array}{l}+ \\
\text { (Conservationist, tourists, } \\
\text { foresters) }\end{array}$ \\
\hline Social & $\begin{array}{l}+ \\
\text { (web of relations between } \\
\text { forest owners) }\end{array}$ & $\begin{array}{c}+++ \\
\text { (Publicity and web relations) }\end{array}$ & $\begin{array}{c}+ \\
\text { (information sharing with the } \\
\text { ONF) }\end{array}$ & $\begin{array}{c}++ \\
\text { (Awareness and web relations) }\end{array}$ \\
\hline Natural (forest) & $\begin{array}{c}+++ \\
(\text { Trees })\end{array}$ & $\begin{array}{c}+++ \\
\text { (Natural environment) }\end{array}$ & $\begin{array}{l}+++ \\
\text { (Trees) }\end{array}$ & $\begin{array}{c}+++ \\
\text { (Natural environment) }\end{array}$ \\
\hline
\end{tabular}

transformation of mountains in recent decades in many European regions, particularly in the Vercors, in which tourism in some locations dates back to the mid-19th century. Table (1) shows the tourism function through the lens of the robustness framework. Tourists take advantage of physical and social infrastructure to produce cultural services from the forest, and conversely, publicity and information about the resource flow back to the users (Table
1, Link 1). Tourists and tourism companies contribute to governance (PIP) in the form of value-added tax, permits, license fees, and elections (Table 1, Link 2). The government uses the tax money from tourists to construct PI that are essential to the development of tourism in the forest (Table 1, Link 3). Infrastructures contribute to the publicity of tourism in the forest and they facilitate tourist activities (Table 1, Link 5). In addition, 
infrastructures provide knowledge for industry and enforce laws on tourism (Table 1, Link 6). Infrastructures collect information on the tourists and their activities in the forest, which can help impose laws and adopt new management strategies for recreational activities.

\section{Nature conservation function}

The Vercors forest belongs to one of the most important ecosystems in Europe and, as such, it is subject to a nature conservation function (Sarvašová et al. 2014). Despite the successful implementation of multifunctional forest management in the Vercors, conflicts between nature conservation and other sectoral policies regarding management of mountain forests were reported from some regions. Table (1) presents the nature conservation function from the perspective of the robustness framework. Conservationists and forest managers (e.g., ONF) help to conserve the forest through utilization of infrastructures (associations, environmental organizations, and scientific studies), and information is gathered on the ecology of the forest (Table 1, Link 1). Forest users participate in electing representatives in governance (Table 1, Link 2). In return, governance produces infrastructures such as PNR, protected areas, and environmental laws that can help in the forest conservation process (Table 1, Link 3). Furthermore, organizations enforce laws that benefit the preservation of nature and thus enhance the effort exerted by conservationists on the forest (Table 1, Link 5). Additionally, organizations contribute to an increase in the nature conservation activities by providing knowledge to users and spreading awareness (i.e., PNR; Table 1, Link 6).

\section{Protective function}

Mountain forests in the Vercors have an important protective function against natural hazards such as rockfall, snow avalanches, and shallow landslides (Aggestam and Wolfslehner 2013). The primary function of the protective forest is to shield people and assets from the impacts of natural hazards. The key products of the forest are the standing trees that act as obstacles to the triggers of mass movements and downslope propagation hazards. Table (1) displays the protective function of the forest from the robustness framework perspective. Users (i.e., forest owners, public, and private organizations, etc.) employ strategies to strengthen the forest with the purpose of protecting infrastructures (Table 1, Link 1); in return, users participate in electing the government (Table 1, Link 2), which, in turn, provides infrastructures that are essential for the operation of this function (Table 1, Link 3). All of these interactions occur while information eventually flows back to the resources.

\section{Exogenous variables}

Although the forest is a system that is governed by social and ecological subsystems, it is also affected by exogenous variables that influence the forest on a global scale. Economic instability has an impact on timber and fuelwood markets and introduces high variability and uncertainty in the stock market. Moreover, global climate change also has an effect on the ecology of the forest (at the regeneration, growth, and survival levels) and, consequently, on the functions of the forest. Additionally, the scarcity of snow has had a significant impact on snow tourism. In the Quatre-Montagnes, negative impacts of climate change were evident for the provision of ecosystem functions. Synergies and trade-offs between the majority of forest functions were found to be sensitive to the choice of management and to climate change (Mina et al. 2017).

\section{ANALYSIS AND DISCUSSION}

\section{Synthesis}

We have explicitly applied the two frameworks (SES and robustness) in a complementary manner as a tool for the institutional analysis of multifunctional forest management. With this, we conceptualized the link between interactions (I) and outcomes (O) within the SES framework. In particular, after acknowledging its powerful capacity for analysis and deduction, we used the SES framework to introduce general support for our institutional analysis. Moreover, through our analysis, we highlighted the importance of the infrastructure concept and the role of spillovers (Anderies et al. 2016) in affecting the outcomes of the forest. For example, a lack of roads can have several effects, one of which is to limit affordance for people to exploit timber in the forest, which in turn may lead to a reduction in the negative effects of tree cutting on specific forest-dwelling species (Paillet et al. 2010). We used the robustness framework to conceptually represent forest multifunctionality because it adequately captures such infrastructure and spillover concepts. From this, one can conclude that there are four functions that are widely practiced in the Quatre-Montagnes forest (timber production, fuelwood production, tourism, and nature conservation; the protection function is not very important in this area, see Table 1). These functions, however, interact in a complex manner (highlighted by the many trade-offs that emerged between functions; i.e., impact of tree removal on the biodiversity and scenic beauty of the forest that impacts tourism and nature conservation) impacting not only the dynamics of the forest as a natural infrastructure but also the production capabilities of the functions themselves. Furthermore, the interactions between functions, as characterized in our analysis, occur on the infrastructure level. This perspective has identified a link between the concept of multifunctional forest management and the multifunctionality of different types of infrastructures, as defined by Anderies et al. (2016). This link emerges from the application of the robustness framework to each function individually, keeping in mind that there are common infrastructures for different functions. Our approach offers a new way of describing multifunctional forest management by associating various types of infrastructures to SES variables relevant to the case study considered. The approach has allowed for the identification and organization of general components that function in the forest and has revealed difficult-to-observe spillovers between the types of infrastructures of different functions. By connecting the multifunctionality of forests to the multifunctionality of infrastructures, we illustrate how qualitative analysis can be used to conceptually describe and organize forest SES components to help design governance and management strategies.

\section{Characterizing dynamics and governance of the forest}

Thanks to our complimentary framework application, we have qualitatively characterized the link between multifunctional forest use and the multifunctionality of infrastructures in an SES context. This characterization has allowed us to conceptually organize the relationship between interactions within the SES framework and the actual outcomes. Knowledge of how the 
Fig. 5. Forest functions from the point of view of the robustness framework's conceptual map. The thicker the arrow, the more important the interaction. Note: DDT $=$ Direction Départementale des Territoire; ONF = Office Nationale des Forêts; CCMV = Communauté de Communes du Massif du Vercors; PNR = Parc Naturel Régional.

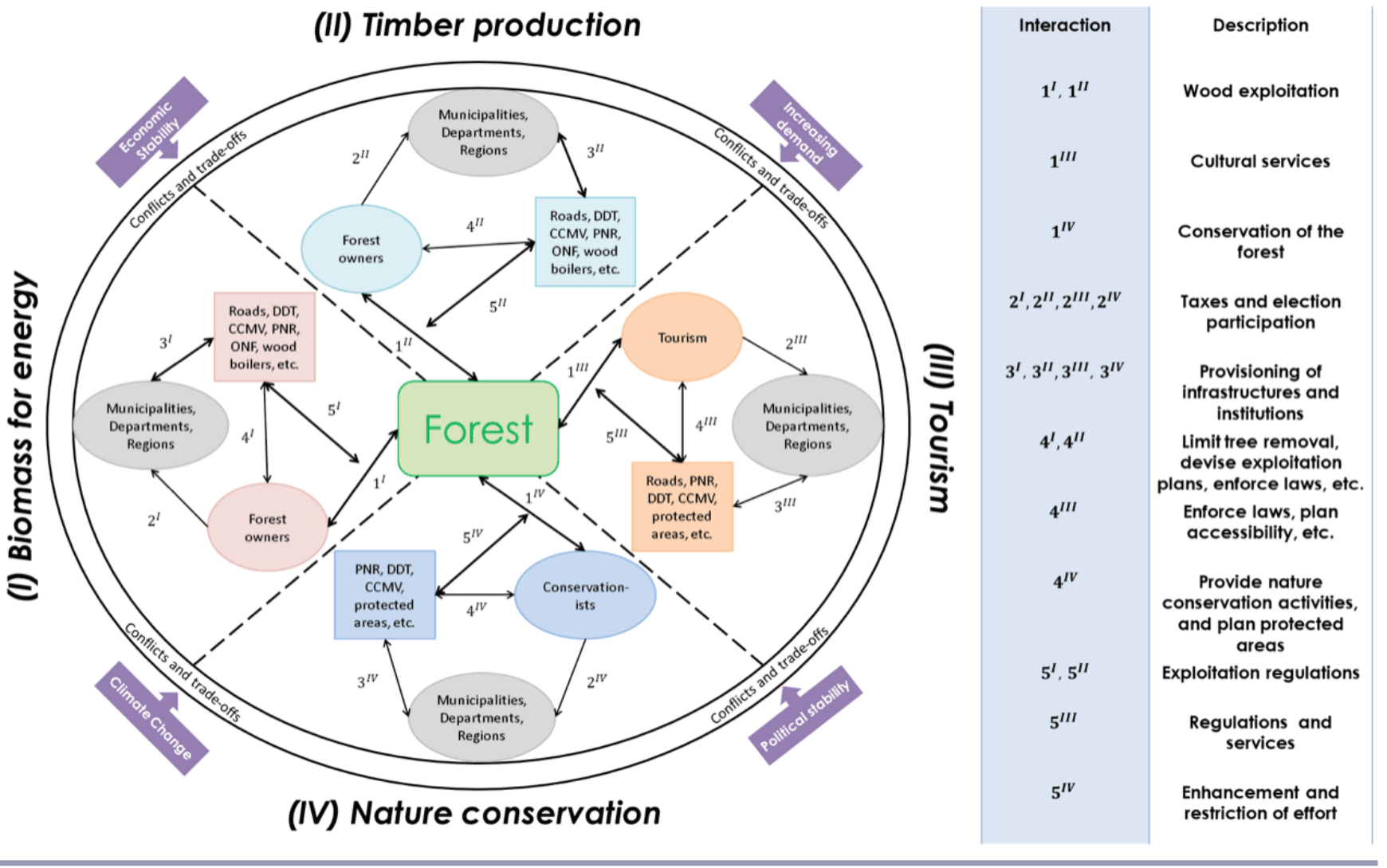

different infrastructures of each function interact to affect one another and to produce resources from the forest is essential from a management perspective (which infrastructures interact and how). Governance, being an infrastructure provider, is a critical point in determining how the exploitation system evolves in the forest. Its role in promoting and maintaining industrial activity through developing infrastructures is essential for the development of functions to comply with market demand. Multifunctional forest management can be difficult to achieve without a proper infrastructure framework and mechanism. Decisions about infrastructure alignment, building, maintenance, or decommissioning are complex because of the many trade-offs involved (Lugo and Gucinski 2000). Our analysis has provided characterization of a multifunctional forest management view of the system with clear connections between the different functionrelated infrastructures. Figure (5) represents a modified conceptual map of the robustness framework that considers the four important functions in the Quatre-Montagnes forest and their governance system.

A function or an infrastructure? The importance of spillover Well-planned design and robust approaches to the conceptualization of forest social-biophysical interactions comprise a critical component of forest management (Prato and Paveglio 2014). The importance increases as the demand for forest provision becomes closely tied to societal incentives. As outlined earlier, managing forests for different functions may be enhanced by carefully designing investments in the provision of associated infrastructures for each function (i.e., social, human, hard humanmade, etc.). For example, prior to introducing new public hard human-made infrastructures, the government must be able to maintain them so as to avoid a cascading failure; this is done through additional investment in infrastructures that can offer affordance for maintenance (human and social infrastructures). Also, recent works (Rose 1986, Frischmann 2005, Anderies et al. 2016) analyze the ways in which the special nature of infrastructure affects both how it is provided and its impact on economic activities. Essential to this argument is thinking carefully about the many ways that infrastructures trigger difficult-to-observe effects that generate value to society. Thinking in terms of the positive and negative effects of infrastructure interactions was used by Anderies et al. (2016) in the coupled infrastructure systems representation. In fact, the authors argued that not considering these effects can distort institutional analysis by placing too much emphasis on the problem of providing infrastructure and allowances for suppliers to capture the benefits of infrastructures while neglecting the importance of the demand for the many benefits that infrastructures may provide. We have identified a link between how multifunctional forest management evolves and an abundance of relevant infrastructures. The present work 
highlights the control of governance on the development of forest functions through the provisioning of infrastructures. Investing in function-related infrastructures may contribute to the progress of this function. In other words, in the Quatre-Montagnes forest, one needs to reinforce both hard and soft infrastructures to enhance multifunctionality. For example, the development of timber function depends on the investment in accessibility infrastructures such as roads. Therefore, a suitable design of infrastructures can contribute to a better application of multifunctional forest management by putting more emphasis on forest function-related infrastructures than on other infrastructures.

Using a qualitative conceptual map, our complementary framework application can identify how the nature of one function-specific infrastructure affects the different natures of other infrastructures. Figure 6 corresponds to the different levels of effect an investment can have on multiple functions in the forest. For example, consider an investment in hard human-made infrastructures for the function of wood removal:

- The first-tier effect (blue in Fig. 6) refers to the (1) effect of investment (green in Fig. 6) on other types of infrastructures found in the same function and (2) the effect on the same type of infrastructures found in other functions. For instance, this effect has an impact on multifunctionality by contributing to the enhancement of accessibility for recreational purposes.

- The second-tier effect (orange in Fig. 6) refers to the effect produced by the intersection of two first-tier effects on infrastructures and functions. In other words, the secondtier effect requires two first-tier effects: one on infrastructure and one on the function. For instance, this effect refers to the need to invest in other types of infrastructures (i.e., social infrastructure: publicity) in the same functions to comply with the market demand.

- The third-tier effect (purple in Fig. 6) refers to the effects produced by only one first-tier effect, either from (1) common infrastructures found in other functions or (2) functions that use the same type of infrastructures. The nature conservation function can also be promoted by considering soft human-made, human, and social infrastructures for tourism, taking advantage of their potential for use in its performance (multifunctionality).

Such investment may increase potential conflicts between multiple forest functions, which then require more social capital between stakeholders (e.g., social infrastructures). This generic view of forest multifunctionality has presented a decision tool for qualitative and systematic investment. It characterizes the different effects that one investment can incur on other infrastructures, and ultimately affect the functions.

\section{Cascading effects and hidden feedbacks}

The decisions on operationalizing multifunctional forest management are complex and persistent critical transitions in the function and structure of the ecosystem. However, it is unknown how these transitions will interact, whether the occurrence of one will increase the likelihood of the occurrence of another or whether they will simply correlate in distant places. Knowledge of how the cascading effects of management actions will have an impact on the system is critical for a multifunctional design. As recognized by Rocha et al. (2018), there are two types of effects. (1) A domino effect refers to a one-way reaction; for instance, in our case, this corresponds to the increase in accessibility for tourism that ultimately enhances the need to preserve the forest (by mobilizing relevant infrastructures) and thus benefits nature conservation. (2) Hidden effects with a two-way interaction; for example, this is seen through recognizing the feedback that occurs between increasing accessibility for tourism and wood removal that could increase conflicts between the two functions. Recognizing these two types of effects at the infrastructure level considers every interaction as both a cascading domino effect and a hidden effect.

Fig. 6. Effect of investments in hard-human made infrastructures for forestry functions. Green signifies investment, blue first-tier effect, orange second-tier effect, and purple third-tier effect. The signs,+++ , and +++ , refer to the importance of the infrastructure to the relevant forest functions (for more information see Table 1 and Appendix 1). Note: DDT $=$ Direction Départementale des Territoire; ONF $=$ Office

Nationale des Forêts; CCMV = Communauté de Communes du Massif du Vercors; PNR $=$ Parc Naturel Régional.

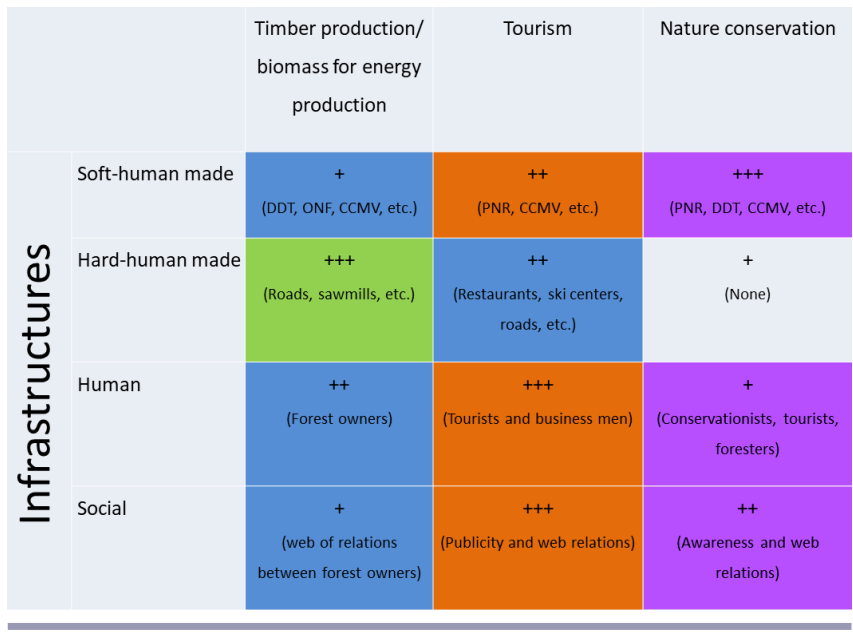

\section{CONCLUSION}

We have developed a method that examines the SES concept with a focus on multifunctional forest management. Through our analysis, we have highlighted the spillovers that can occur between functions through the concept of infrastructures (see Fig. 6). Using an example, we demonstrated that the resulting complementary framework application can be used to examine problems associated with shared and multifunctional infrastructures for multiple forest functions. The picture that emerges from our methodological applications shows that careful infrastructure investment strategies are needed to directly enable multifunctional forest management. Moreover, it is essential to grasp the relationship among the contributing infrastructures and their inner relations with a focus on the notion of spillovers. The complexity that can arise from the interactions of different forest functions admitting different (and perhaps conflicting) objectives would argue against highly simplified approaches of multifunctional forest application. 
The economic development of forest functions has to deal with certain constraints in managing multifunctionality: the fragility of the ecosystem and the geographic constraints that limit the accessibility to the forest. The main aspect influencing the outcomes of forest functions is the availability of infrastructures, highlighting their importance in enabling multifunctional forest management. In this regard, it is necessary that the design, establishment, and management of infrastructures be carried out by considering the values and functions provided by the forest. We have provided insight for analyzing and designing infrastructural systems that implement multifunctional forest management. We have also highlighted the concept of spillovers and their importance in forest governance, and especially in the context of multifunctionality. In particular, when connecting the performance of multifunctional forest management to the shared nature of infrastructures, the concept of spillover is able to highlight the mutual effect of infrastructure investment on different forest functions. However, because of the nature of the qualitative assessment we adopted, much is needed in formalizing spillovers in a comprehensive governance theory for multifunctional forests. In particular, there is a need for more comparative in-depth case studies using the same infrastructureconnected variables measured with the same protocol.

Our methodology offers prospects for a direct link between the SES and robustness frameworks. This link is illustrated by the ability of the robustness framework to conceptually describe the complex relationship between the interaction (I) and outcomes (O) found in the SES framework for the case of SESs that depend heavily on infrastructures. This work can thus be useful for deriving conclusions on the governance of SESs. We have applied the methodological nature of our work to the Quatre-Montagnes forest to facilitate the comprehension of our approach. Although we have chosen a forest case study to highlight the multifunctionality concept, we note that this concept has recently gained popularity within managed ecosystems, i.e., rivers, streams, and lakes (Podolak 2012, Munch et al. 2016, Habersack et al. 2018), agricultural systems (Ricart et al. 2019), and fisheries (Mulazzani et al. 2019). We hope that this work serves as a first step toward the initiation of the multifunctionality concept with existing SES frameworks.

Our analysis can open the door to developing operational tools that can help to better devise multifunctional management strategies by considering the social and ecological aspects of an SES. One example of such use of the robustness framework can be found in the paper by Muneepeerakul and Anderies (2017), in which the authors operationalize the framework's conceptual map to build a mathematical model that explores the circumstances surrounding the emergence of stable governance. There is still much to be gained from merging mathematical tools (dynamical system theory, viability theory, etc.) in the framework's conceptual map that can contribute to more generic models for SES management.

Responses to this article can be read online at: http://www.ecologyandsociety.org/issues/responses. php/11424

\section{Acknowledgments:}

This research has been funded by the ANR (Agence Nationale de la Recherche) under the VIRGO project (ANR-16-CE03-0003) and the region of Auvergne. Moreover, this research was conducted on the Long-Term Socio-Ecosystem Research platform LTSER "Zone Atelier Alpes", a member of the ILTER-Europe network.

\section{LITERATURE CITED}

Achard, B. 2011. Conditions socio-économiques d'une augmentation de la récolte de bois en montagne. Thesis. ISARA, Lyon, France.

Aggestam, F., and B. Wolfslehner. 2013. Mountain forests and land use scenarios: a review and scenario development. ARANGE Deliverable D3.2. ARANGE Project, Vienna, Austria.

AGRESTE. 2014. Forêts et industries du bois. Ministère de l'agriculture et de l'alimentation, Paris, France. http://agreste. agriculture.gouv.fr/IMG/pdf/Gar14p124-131.pdf

Anderies, J. M., M. A. Janssen, and E. Ostrom. 2004. A framework to analyze the robustness of social-ecological systems from an institutional perspective. Ecology and Society 9(1):18. https://doi. org/10.5751/ES-00610-090118

Anderies, J. M., M. A. Janssen, and E. Schlager. 2016. Institutions and the performance of coupled infrastructure systems. International Journal of the Commons 10(2):495-516. https://doi. org/10.18352/ijc. 651

Avocat, H., A. Tabourdeau, C. Chauvin, and M.-H. De Sede Marceau. 2012. Energy and wood in the French Alps: strategies for an uncertain resource. Revue de Géographie Alpine 99(3). https://doi.org/10.4000/rga.1616

Ban, N. C., L. S. Evans, M. Nenadovic, and M. Schoon. 2015. Interplay of multiple goods, ecosystem services, and property rights in large social-ecological marine protected areas. Ecology and Society 20(4):2. https://doi.org/10.5751/ES-07857-200402

Benson, M. H., and R. K. Craig. 2014. The end of sustainability. Society and Natural Resources 27:777-782. https://doi. org/10.1080/08941920.2014.901467

Bizikova, L., M. Nijnik, and T. Kluvanková-Oravská. 2012. Sustaining multifunctional forestry through the developing of social capital and promoting participation: a case of multiethnic mountain communities. Small-scale Forestry 11(3):301-319. https://doi.org/10.1007/s11842-011-9185-8

Bonan, G. B. 2008. Forests and climate change: forcings, feedbacks, and the climate benefits of forests. Science 320 (5882):1444-1449. https://doi.org/10.1126/science.1155121

Brock, W. A., and S. R. Carpenter. 2007. Panaceas and diversification of environmental policy. Proceedings of the National Academy of Sciences 104(39):15206-15211. https://doi. org/10.1073/pnas.0702096104

Bugmann, H., T. Cordonnier, H. Truhetz, and M. J. Lexer. 2017. Impacts of business-as-usual management on ecosystem services in European mountain ranges under climate change. Regional 
Environmental Change 17(1):3-16. https://doi.org/10.1007/ s10113-016-1074-4

Ciancio, O., and S. Nocentini. 1997. The forest and man: the evolution of forestry thought from modern humanism to the culture of complexity, systemic silviculture and management on a natural basis. Pages 21-114 in $\mathrm{O}$. Ciancio, editor. The forest and man. Accademia Italiana di Scienze Forestali, Florence, Italy.

Cole, D. N. 1993. Minimizing conflict between recreation and nature conservation. Pages 105-122 in D. S. Smith, and P. C. Hellmund, editors. Ecology of greenways: design and function of linear conservation areas. University of Minnesota Press, Minneapolis, Minnesota, USA. (online) URL: https://www.fs. fed.us/rm/pubs_other/rmrs_1993_cole_d001.pdf

Cordonnier, T., C. Ginistry, J.-D. Mathias, F. De Morogues, J.-L. Dupouey, F. Courdier, J.-C. Hervé, A. Caron, and X. Rochel. 2014. Projet ANR-09-STRA-02-01. FORGECO. Programme SYSTERRA 2009. Compte-rendu de fin de projet. Agence Nationale de Recherche, Paris, France. (online) URL: https:// prodinra.inra.fr/record/407077

Cox, M. 2014. Applying a social-ecological system framework to the study of the Taos Valley irrigation system. Human Ecology 42(2):311-324. https://doi.org/10.1007/s10745-014-9651-y

Dunford, R., P. Harrison, A. Smith, J. Dick, D. N. Barton, B. Martin-Lopez, E. Kelemen, S. Jacobs, H. Saarikoski, F. Turkelboom, W. Verheyden, J. Hauck, P. Antunes, R. Aszalós, O. Badea, F. Baró, P. Berry, L. Carvalho, G. Conte, B. Czúcz, G. Garcia Blanco, D. Howard, R. Giuca, E. Gomez-Baggethun, B. Grizetti, Z. Izakovicova, L. Kopperoinen, J. Langemeyer, S. Luque, D. M. Lapola, G. Martinez-Pastur, R. Mukhopadhyay, S. B. Roy, J. Niemelä, L. Norton, J. Ochieng, D. Odee, I. Palomo, P. Pinho, J. Priess, G. Rusch, S.-R. Saarela, R. Santos, J. T. van der Wal, A. Vadineanu, Á. Vári, H. Woods, and V. Yli-Pelkonen. 2018. Integrating methods for ecosystem service assessment: experiences from real world situations. Ecosystem Services 29:499-514. https://doi.org/10.1016/j.ecoser.2017.10.014

European Observatory of Mountain Forests. 2000. White book 2000 on mountain forests in Europe. European Union DG Agriculture and EOMF, Saint Jean d'Arvey, France. (online) URL: https://lib.icimod.org/record/10563

Fleischman, F. D., K. Boenning, G. A. Garcia-Lopez, S. Mincey, M. Schmitt-Harsh, K. Daedlow, M. Lopez, X. Basurto, B. Fischer, and E. Ostrom. 2010. Disturbance, response, and persistence in self-organized forested communities: analysis of robustness and resilience in five communities in Southern Indiana. Ecology and Society 15(4):9. https://doi.org/10.5751/ ES-03512-150409

Frischmann, B. M. 2005. An economic theory of infrastructure and commons management. Minnesota Law Review 89:917-1030. (online) URL: https://papers.ssrn.com/sol3/papers.cfm?abstract_id=588424 \#\#

Frischmann, B. M. 2007. Infrastructure commons in economic perspective. First Monday 12(6). https://doi.org/10.5210/fm. v12i6.1901

Frischmann, B. M. 2012. Infrastructure: the social value of shared resources. Oxford University Press, Oxford, UK. https://doi. org/10.1093/acprof:oso/9780199895656.001.0001
Gamfeldt, L., T. Snäll, R. Bagchi, M. Jonsson, L. Gustafsson, P. Kjellander, M. C. Ruiz-Jaen, M. Fröberg, J. Stendahl, C. D. Philipson, G. Mikusiński, E. Andersson, B. Westerlund, H. Andrén, F. Moberg, J. Moen, and J. Bengtsson. 2013. Higher levels of multiple ecosystem services are found in forests with more tree species. Nature Communications 4:1340. https://doi.org/10.1038/ $\underline{\text { ncomms } 2328}$

Gonzales-Redin, J., S. Luque, L. Poggio, R. Smith, and A. Gimona. 2016. Spatial Bayesian belief networks as a planning decision tool for mapping ecosystem services trade-offs on forested landscapes. Environmental Research 144:15-26. https:// doi.org/10.1016/j.envres.2015.11.009

Habersack, H., M. Eder, and R. Samek. 2018. Preface: multifunctionality of large rivers. Hydrobiologia 814(1):1-3. https://doi.org/10.1007/s10750-017-3460-4

Hinkel, J., P. W. G. Bots, and M. Schlüter. 2014. Enhancing the Ostrom social-ecological system framework through formalization. Ecology and Society 19(3):51. https://doi.org/10.5751/ES-06475-190351

Johnson, K. N., and F. G. Swanson. 2009. Historical context of old growth forests in the Pacific Northwest: policy, practices, and competing worldviews. Pages 12-28 in T. A. Spies and S. L. Duncan, editors. Old growth in a new world: a Pacific Northwest icon reexamined. Island, Washington, D.C., USA.

Kennedy, J. J., and N. E Koch. 2004. Viewing and managing natural resources as human-ecosystem relationships. Forest Policy Economics 6(5):497-504. https://doi.org/10.1016/j.forpol.2004.01.002

Koskela, J., A. Buck, and E. Teissier du Cros. 2007. Climate change and forest genetic diversity: implications for sustainable forest management in Europe. Biodiversity Intenational, Rome, Italy. (online) URL: http://www.euforgen.org/fileadmin/bioversity/ publications/pdfs/1216.pdf

Kouplevatskaya-Buttoud, I. 2009. Adaptation to change and redesigning of governance systems: cases from small-scale rural forestry. Small-scale Forestry 8:231-247. https://doi.org/10.1007/ s11842-009-9073-7

Lafond, V., T. Cordonnier, Z. Mao, and B. Courbaud. 2017. Trade-offs and synergies between ecosystem services in unevenaged mountain forests: evidences using Pareto fronts. European Journal of Forest Research 136(5-6):997-1012. https://doi. org/10.1007/s10342-016-1022-3

Levin, S. A. 1998. Ecosystems and the biosphere as complex adaptive systems. Ecosystems 1(5):431-436. https://doi. org/10.1007/s100219900037

Liu, J., T. Dietz, S. R. Carpenter, M. Alberti, C. Folke, E. Moran, A. N. Pell, P. Deadman, T. Kratz, J. Lubchenco, E. Ostrom, Z. Ouyang, W. Provencher, C. L. Redman, S. H. Schneider, and W. W. Taylor. 2007. Complexity of coupled human and natural systems. Science 317(5844):1513-1516. https://doi.org/10.1126/ science. 1144004

Lugo, A. E., and H. Gucinski. 2000. Function, effects, and management of forest roads. Forest Ecology and Management 133:249-262. https://doi.org/10.1016/S0378-1127(99)00237-6

McGinnis, M. D., and E. Ostrom. 2014. Social-ecological system framework: initial changes and continuing challenges. Ecology and Society 19(2):30. https://doi.org/10.5751/ES-06387-190230 
Mckercher, B. 1992. Tourism as a conflicting land use. Annals of Tourism Research 19:467-481. https://doi.org/10.1016/0160-7383 (92)90131-8

Messier, C, K. J. Puettmann, and K. D. Coates. 2013. The complex adaptive system. A new integrative framework for understanding and managing the world forest. Pages 327-341 in C. Messier, K. J. Puettmann, and K. D. Coates, editors. Managing forests as complex adaptive systems: building resilience to the challenge of global change. Routledge, New York, New York, USA.

Millennium Ecosystem Assessment (MEA). 2005. Ecosystems and human well-being: synthesis. Island, Washington, D.C., USA. (online) URL: https://www.millenniumassessment.org/documents/ document.356.aspx.pdf

Mina, M., H. Bugmann, T. Cordonnier, F. Irauschek, M. Klopcic, M. Pardos, and M. Cailleret. 2017. Future ecosystem services from European mountain forests under climate change. Journal of Applied Ecology 54:389-401. https://doi.org/10.1111/1365-2664.12772

Ministère de l'Agriculture et de la Peche. 2001. Law on orientation of forest. Ministère de l'Agriculture et de la Peche, Paris, France.

Mulazzani, L., L. Camanzi, and G. Malorgio. 2019. Multifunctionality in fisheries and the provision of public goods. Ocean and Coastal Management 168:51-62. https://doi. org/10.1016/j.ocecoaman.2018.10.037

Münch, A., S. P. P. Nielsen, V. J. Racz, and A.-M. Hjalager. 2016. Towards multifunctionality of rural natural environments? An economic valuation of the extended buffer zones along Danish rivers, streams and lakes. Land Use Policy 50:1-16. https://doi. org/10.1016/j.landusepol.2015.08.024

Muneepeerakul, R., and J. M. Anderies. 2017. Strategic behaviors and governance challenges in social-ecological systems. Earth's Future 5:865-876. https://doi.org/10.1002/2017EF000562

Nagendra, H. 2007. Drivers of reforestation in human-dominated forests. Proceedings of the National Academy of Sciences 104:15218-15223. http://dx.doi.org/10.1073/pnas.0702319104

Nasi, R., S. Wunder, and J. J. Campos A. 2002. Forest ecosystem services: can they pay our way out of deforestation? CIFOR for the Global Environmental Facility, Bogor, Indonesia. (online) URL: http://www.cifor.org/publications/pdf files/Books/BNasi0201. pdf

Nocentini, S., G. Buttoud, O. Ciancio, and P. Corona. 2017. Managing forests in a changing world: the need for a systemic approach. A review. Forest Systems 26(1):eR01. https://doi. org/10.5424/fs/2017261-09443

Nordic Centre for Spatial Development (Nordregio). 2004. Mountain areas in Europe: analysis of mountain areas in $E U$ member states, acceding and other European countries. Final report. European Commission, Brussels, Belgium. (online) URL: https://ec.europa.eu/regional_policy/sources/docgener/studies/pdf/ montagne/mount1.pdf

Oberlack, C., P. LaHaela Walter, J. Schmerbeck, and B. K. Tiwari. 2015. Institutions for sustainable forest governance: robustness, equity, and cross-level interactions in Mawlyngbna, Meghalaya, India. International Journal of the Commons 9(2):670-697. http:// doi.org/10.18352/ijc. 538
Onida, M. 2009. The Alps-eight countries, a single territory by Permanent Secretariat of the Alpine Convention. Permanent Secretariat of the Alpine Convention, Innsbruck, Austria.

Ostrom, E. 2009. A general framework for analyzing sustainability of social-ecological systems. Science 325:419-422. https://doi.org/10.1126/science.1172133

Ostrom, E., M. A. Janssen, and J. M. Anderies. 2007. Going beyond panaceas. Proceedings of the National Academy of Sciences 104:15176-15178. https://doi.org/10.1073/pnas.0701886104

Paillet, Y., L. Bergès, J. Hjältén, P. Òdor, C. Avon, M. BernhardtRömermann, R.-J. Bijlsma, L. De Bruyn, M. Fuhr, U. Grandin, R. Kanka, L. Lundin, S. Luque, T. Magura, S. Matesanz, I. Mészáros, M.-T. Sebastià, W. Schmidt, T. Standovár, B. Tóthmérész, A. Uotila, F. Valladares, K. Vellak, and R. Virtanen. 2010. Biodiversity differences between managed and unmanaged forests: meta-analysis of species richness in Europe. Conservation Biology 24(1):101-112. https://doi.org/10.1111/j.1523-1739.2009.01399. $\underline{\mathrm{X}}$

Partelow, S., and K. Winkler. 2016. Interlinking ecosystem services and Ostrom's framework through orientation in sustainability research. Ecology and Society 21(3):27. https://doi. org/10.5751/es-08524-210327

Partelow, S., M. Glaser, S. Solano Arce, R. Sá Leitão Barboza, and A. Schlüter. 2018. Mangroves, fishers, and the struggle for adaptive comanagement: applying the social-ecological systems framework to a marine extractive reserve (RESEX) in Brazil. Ecology and Society 23(3):19. https://doi.org/10.5751/ES-10269-230319

Podolak, K. 2012. Multifunctional riverscapes: stream restoration, Capability Brown's water features, and artificial whitewater. Dissertation. University of California at Berkeley, Berkeley, California. (online) URL: https://escholarship.org/uc/item/0c18207s

Prato, T., and T. B. Paveglio. 2014. An integrated conceptual framework for adapting forest management practices to alternative futures. International Journal of Forestry Research 2014:321345. https://doi.org/10.1155/2014/321345

Puech, J. 2009. Mise en valeur de la forêt française et développement de la filière bois, mission confiée à Jean Puech, ancien ministre. Rapport remis à Monsieur Nicolas Sarkozy, Président de la République. Vie Publique, Paris, France. (online) URL: https:// www.vie-publique.fr/sites/default/files/rapport/pdf/094000287.pdf

Puettmann, K. J., K. D. Coates, and C. Messier. 2009. A critique of silviculture: managing for complexity. Island, Washington, D. C., USA. (online) URL: http://frst411.sites.olt.ubc.ca/files/2015/01/ A-Critique-of-Silviculture.pdf

Ramaswami, A., C. Weible, D. Main, T. Heikkila, S. Siddiki, A. Duvall, A. Pattison, and M. Bernard. 2012. A social-ecologicalinfrastructural systems framework for interdisciplinary study of sustainable city systems. Journal of Industrial Ecology 16 (6):801-813. https://doi.org/10.1111/j.1530-9290.2012.00566.x

Ricart, S., N. Kirk, and A. Ribas. 2019. Ecosystem services and multifunctional agriculture: unravelling informal stakeholders' perceptions and water governance in three European irrigation systems. Environmental Policy and Governance 29(1):23-34. https://doi.org/10.1002/eet.1831 
Rocha, J. C., G. Peterson, Ö. Bodin, and S. Levin. 2018. Cascading regime shifts within and across scales. Science 362 (6421):1379-1383. http://doi.org/10.1126/science.aat7850

Rose, C. 1986. The comedy of the commons: custom, commerce, and inherently public property. University of Chicago Law Review 53(3):711-781. (online) URL: https://digitalcommons.law.yale. $\underline{\text { edu/cgi/viewcontent } \text {.cgi? article }=2827 \& \text { context }=\text { fss papers }}$

Sarvašová, Z., E. Cienciala, J. Beranová, M. Vančo, A. Ficko, and M. Pardos. 2014. Analysis of governance systems applied in multifunctional forest management in selected European mountain regions. Central European Forestry Journal 60 (3):159-167. https://doi.org/10.2478/forj-2014-0017

Schlüter, M., J. Hinkel, P. W. G. Bots, and R. Arlinghaus. 2014. Application of the SES framework for model-based analysis of the dynamics of social-ecological systems. Ecology and Society 19(1):36. https://doi.org/10.5751/ES-05782-190136

Schmithüsen, F. 2007. Multifunctional forestry practices as a land use strategy to meet increasing private and public demands in modern societies. Journal of Forest Science 53(No. 6):290-298. https://doi.org/10.17221/2016-JFS

Seidl, R., and M. J. Lexer. 2013. Forest management under climatic and social uncertainty: trade-offs between reducing climate change impacts and fostering adaptive capacity. Journal of Environmental Management 114:461-469. https://doi. org/10.1016/j.jenvman.2012.09.028

Slee, B. 2012. Present opportunities for sustainable and multifunctional forest management for the development of rural areas. Italian Journal of Forest and Mountain Environments 67 (2):147-160. https://doi.org/10.4129/IFM.2012.2.01

Spiecker, H. 2003. Silvicultural management in maintaining biodiversity and resistance of forests in Europe-temperate zone. Journal of Environmental Management 67(1):55-65. https://doi. org/10.1016/S0301-4797(02)00188-3

Steinhäußer, R., R. Siebert, A. Steinführer, and M. Hellmich. 2015. National and regional land-use conflicts in Germany from the perspective of stakeholders. Land Use Policy 49:183-194. https://doi.org/10.1016/j.landusepol.2015.08.009

Tenerelli, P., U. Demšar, and S. Luque. 2016. Crowdsourcing indicators for cultural ecosystem services: a geographically weighted approach for mountain landscapes. Ecological Indicators 64:237-248. https://doi.org/10.1016/j.ecolind.2015.12.042

Tissot, W., and Y. Kohler. 2013. Integration of nature protection in forest policy in France. INTEGRATE Country Report. EFICENT-OEF, Freiburg, Germany.

Vogt, J. M., G. B. Epstein, S. K. Mincey, B. C. Fischer, and P. McCord. 2015. Putting the "E" in SES: unpacking the ecology in the Ostrom social-ecological system framework. Ecology and Society 20(1):55. https://doi.org/10.5751/ES-07239-200155

von Detten, R. 2011. Sustainability as a guideline for strategic planning? The problem of long-term forest management in the face of uncertainty. European Journal of Forest Research 130 (3):451-465. https://doi.org/10.1007/s10342-010-0433-9
Walker, B., C. S. Holling, S. R. Carpenter, and A. Kinzig. 2004. Resilience, adaptability, and transformability in social-ecological systems. Ecology and Society 9(2):5. https://doi.org/10.5751/ ES-00650-090205

Yu, D. J., M. R. Qubbaj, R. Muneepeerakul, J. M. Anderies, and R. M. Aggarwal. 2015. Effect of infrastructure design on commons dilemmas in social-ecological system dynamics. Proceedings of the National Academy of Sciences 112 (43):13207-13212. https://doi.org/10.1073/pnas.1410688112 


\section{Appendix - Data extraction and measurement}

The data used to build up the analysis has been taken either from French national project [FORGECO 2014], European project [ARANGE 2015], or literature about the case study from a search in the Scopus data base; for more information about the source of data, see table (S1). FORGECO project aimed to develop a territorial forestry approach based on the principles of integrated management of ecosystems that can accompany and organize the increase in harvesting of the resource and better preservation of biodiversity and soil quality. There were one mountain forest case study approached, Quatre-Montagne forests. The survey focuses on the participatory and adaptive approach to forest management expertise and its ecological and socio-economic vulnerabilities, and the development and evaluation of scenarios for intensifying forest management. In order to allow spatial and temporal integration of information and to support decision-making process, the project is based on the construction of decision-making tools, each of which possesses a generic character: (i) model resource dynamics and mobilization (ii) habitat quality model (iii) scenario analysis using the production boundary method, (iv) resilience and scenario viability analysis, (v) participative approach structured by the method of the territory game [Lardon et al. 2016]. Moreover, ARANGE project [Bugmann et al. 2017] objective was to analyze the multifunctional forest management for several case studies in Europe (seven mountain forests across Europe; Montes de Valsain (Spain), Quatre-Montagne (France), Montafon (Austria), Sneznik (Slovenia), Vilhelmina (Sweden), Kozie Chrbty (Slovakia), Shiroka Laka (Bulgaria)). This scientific synthesis integrated the findings from generic and case study specific analysis to develop a web-based decision support tool box for multifunctional mountain forest management to support interested stakeholders beyond the time span of the project. The main bases for the project are (i) the use of regional case studies, (ii) stakeholder's involvement in the analysis, (iii) the use of models and tools to predict forest conditions and assess ecosystem services, and (iv) establishing new plans and decisions support tools.

The processes of diagnosing important SES framework variables were conducted by the following steps: 
1- Identify the main component of the Quatre-Montagne forest SES (governance system, resource units, resource system, and users).

2- Describe the natural variables that affect each of the forest functions and eventually the governance revolving around them.

3- Identify the general action situation in which the functions interact.

4- Explore the links and relations between governance and forest functions' performance.

These four steps require figuring out which variables from the SES framework are essential and descriptive. Using the data collected, we use two types of assessment methods for variables' importance:

1- The assessment of the variables from the literature and reports (found in table S1) of the projects depending on the language of the text in which they are described in (see assessment in table $\mathrm{S} 1$ ).

2- Authors' knowledge and expertise on the case study, which determine the variables and infrastructures that are most relevant to the function

As mentioned in the main text, the qualitative comparisons that describe the variables in the SES framework (moderate, strong, high, low) are relative to other mountain forests studied by the ARANGE project. For this, we mention that these case studies are already compared with each other within the text's language of analysis and studies of the ARANGE project.

Moreover, building on the description offered by the SES framework analysis, we constructed the robustness framework analysis by describing its conceptual map for every forest function, essentially through identifying the main components of the robustness framework and characterizing their interactions. Furthermore, the importance of types of infrastructures for each forest function $(+,++$, and +++$)$ is measured by the criteria described above as well. We give the following examples to facilitate the assessment comprehension:

- We conclude through the SES framework's analysis that accessibility is a main issue for the wood production function (see variable I5-infrastructure investment activities and RS4-human constructed facilities), which implicates that hard human-made infrastructures, which are mainly composed of roads, are of a great importance for the function. This implies the +++ measure. 
- Variables A6 (norms/social capital), A7 (Knowledge of the SES), O1 (social performance measures) suggest that nature conservation requires a lot of social capital to function and develop implying the importance of soft-human made infrastructures, which are presented by a set of rules. This implies the +++ measure.

- Variable I2 (Information sharing) advocates that the web of relations between forest function actors are important to increase the performance of the nature conservation function, which implies the importance of social infrastructures. Although the hardhuman made infrastructure is important, one can qualitatively evaluate through author's expertise and literature language that the infrastructure is not as important as the norms and rules (soft-human made infrastructure) for the performance of nature conservation. This implies the ++ measure. 
Table S1. A table presenting the relevant SES framework variables, their assessment method, and the data used to for the assessment method (source of data and type of study)

\begin{tabular}{|c|c|c|}
\hline Data used for & Source (type of study) & Assessment \\
\hline RS1 - sectors & $\begin{array}{l}\text { Mountain areas in Europe } 2004 \text { (Reports), FORGECO } \\
2014 \text { (French national project), ARANGE } 2015 \\
\text { (European project) }\end{array}$ & $\begin{array}{l}\text { These projects highlighted the different functions and their importance (tourism, wood production, and } \\
\text { forest conservation), and as such, they studied the multifunctional forest management shedding light on the } \\
\text { different conflicts that arise between them. }\end{array}$ \\
\hline $\begin{array}{l}\text { RS2 - clarity of system } \\
\text { boundaries }\end{array}$ & Tissot and Yann 2013 (Report) & $\begin{array}{c}\text { This reference analyzed the forest policy in France, explaining the property rights of owners including } \\
\text { their property boundaries. }\end{array}$ \\
\hline $\begin{array}{l}\text { RS3 - size of resource } \\
\text { system }\end{array}$ & $\begin{array}{l}\text { FORGECO } 2014 \text { (French national project), ARANGE } 2015 \\
\text { (European project), Tenerelli et al. } 2016 \text { (Article) }\end{array}$ & The projects clearly defined the size of the forest through spatial measurements and field work. \\
\hline $\begin{array}{l}\text { RS4 - human constructed } \\
\text { facilities }\end{array}$ & $\begin{array}{c}\text { Achard } 2011 \text { (Report), } \begin{array}{c}\text { FORGECO } 2014 \text { (French national } \\
\text { project) }\end{array}\end{array}$ & $\begin{array}{c}\text { The references clearly stated the different human built facilities in the forest (saw mills, roads, } \\
\text { resorts, hotels, etc.) }\end{array}$ \\
\hline $\begin{array}{l}\text { RS5 - productivity of } \\
\text { the system }\end{array}$ & FORGECO 2014 (French national project) & $\begin{array}{l}\text { The project presented the different tree species found in the forest (e.g., Norway Spruce, silver fir, } \\
\text { European beech) and discussed their abundance in the public and private forests }\end{array}$ \\
\hline $\begin{array}{l}\text { RS7 - predictability of } \\
\text { the system dynamics }\end{array}$ & $\begin{array}{c}\text { FORGECO } 2014 \text { (French national project), ARANGE } 2015 \\
\text { (European project), Mathias et al. 2015 (Article), } \\
\text { Lardon et al. } 2016 \text { (Book chapter) }\end{array}$ & $\begin{array}{l}\text { Mathias et al. [2015] builds a mathematical model based on empirical biophysical data for the forest growth } \\
\text { (data includes: tree regeneration, competition between small and big trees, mortalities, light } \\
\text { interception, tree diameters, deadwood and biodiversity, etc.). The article also tests different wood } \\
\text { removal scenarios and predicts their impact on the forest. Moreover, FORGECO [2014] and ARANGE [2015] also } \\
\text { analyze different multifunctional forest management scenarios predicting their impact on the forest as well } \\
\text { as on the performance of other functions through diverse methods [e.g., method of territory game] }\end{array}$ \\
\hline RS9 - location & $\begin{array}{l}\text { Avocat et al. } 2012 \text { (Article), FORGECO } 2014 \text { (French } \\
\text { national project), ARANGE 2015 (European project), } \\
\text { Mathias et al. } 2015 \text { (Article), Lardon et al. } 2016 \\
\text { (Book chapter), etc. }\end{array}$ & $\begin{array}{c}\text { The Quatre-Montagne forest is located in the Grenoble agglomeration, at borders between northern and } \\
\text { southern French Alps with a mountainous location }\end{array}$ \\
\hline $\begin{array}{l}\text { GS1 - government } \\
\text { organizations }\end{array}$ & $\begin{array}{l}\text { Kouplevatskaya-Buttoud } 2009 \text { (Article), Tissot and } \\
\text { Yann } 2013 \text { (Report), Sarvasova et al. } 2014 \\
\text { (Article), ARANGE } 2015 \text { (European project) }\end{array}$ & $\begin{array}{l}\text { The references suggest high presence of government organizations. All exploitation activities are referred } \\
\text { to legal license and documents issued by government organization. For example, the ONF (National Forestry } \\
\text { Office) is one of the important government organizations with authority overlapping on regional, } \\
\text { departmental, and communal levels. }\end{array}$ \\
\hline $\begin{array}{l}\text { GS2 - nongovernment } \\
\text { organization }\end{array}$ & $\begin{array}{l}\text { Tissot and Yann 2013 (Report), FORGECO } 2014 \text { (French } \\
\text { national project), Sarvasova et al. } 2014 \text { (Article) } \\
\text { ARANGE } 2015 \text { (European project) }\end{array}$ & $\begin{array}{l}\text { The sources clearly outline the different nongovernmental organizations that interplay in the Quatre- } \\
\text { Montagne, which ranges from organizations with exploitation and recreational objectives to organizations } \\
\text { with nature conservation objectives. In addition, Sarvasova et al. [2014] assesses the contribution of such }\end{array}$ \\
\hline
\end{tabular}




\begin{tabular}{|c|c|c|}
\hline GS3 - network structure & $\begin{array}{l}\text { Tissot and Yann 2013 (Report), FORGECO } 2014 \text { (French } \\
\text { national project), ARANGE } 2015 \text { (European project), } \\
\text { Kouplevatskaya-Buttoud } 2009 \text { (Article) }\end{array}$ & $\begin{array}{l}\text { The network structure is described as a top-down complex network with different governmental and } \\
\text { nongovernmental organizations interacting on three different levels. Figure } 2 \text { in the main text explains the } \\
\text { different levels of government organizations and the documents that are issued at each level. }\end{array}$ \\
\hline $\begin{array}{l}\text { GS4 - property rights } \\
\text { systems }\end{array}$ & Tissot and Yann 2013 (Report) & $\begin{array}{c}\text { Forest property rights are well known through a legal system determined by the French government. } \\
\text { Nonetheless, Despite the efforts of property consolidation via exchange fairs or via the law, changes are } \\
\text { slow. Forest is a property that is seldom exchanged. }\end{array}$ \\
\hline GS5 - operational rules & $\begin{array}{l}\text { Achard } 2011 \text { (Report), Tissot and Yann } 2013 \\
\text { (Report), ARANGE } 2015 \text { (European project), FORGECO } \\
2014 \text { (French national project) }\end{array}$ & $\begin{array}{c}\text { Operational rules are clearly defined through a legal system that gives licenses based on exploitation } \\
\text { constraints }\end{array}$ \\
\hline $\begin{array}{l}\text { GS6 - collective choice } \\
\text { rules }\end{array}$ & $\begin{array}{l}\text { Tissot and Yann } 2013 \text { (Report), ARANGE } 2015 \\
\text { (European project), Kouplevatskaya-Buttoud } 2009 \\
\text { (Article) }\end{array}$ & $\begin{array}{l}\text { Defined by the French decentralization system, local communities admit an increasing role in defining the } \\
\text { rules for exploitation in the Quatre-Montagne, mainly though the CCMV (community of communes of the Vercors } \\
\text { massif). }\end{array}$ \\
\hline $\begin{array}{l}\text { GS8 - monitoring and } \\
\text { sanctioning rules }\end{array}$ & $\begin{array}{c}\text { Tissot and Yann } 2013 \text { (Report), ARANGE } 2015 \\
\text { (European project) }\end{array}$ & $\begin{array}{l}\text { The monitoring of French forest policy is a very important task. Various instruments are designed to } \\
\text { evaluate and monitor national and regional processes, and programs established by the government. }\end{array}$ \\
\hline $\begin{array}{l}\text { RU1 - resource unit } \\
\text { mobility }\end{array}$ & $\begin{array}{l}\text { Avocat et al. 2012 (Article), FORGECO } 2014 \text { (French } \\
\text { national project), ARANGE 2015 (European project), } \\
\text { Mathias et al. } 2015 \text { (Article), Lardon et al. } 2016 \\
\text { (Book chapter), etc. }\end{array}$ & $\begin{array}{l}\text { As trees are the main producer of wood and reinforce of recreation and conserver of nature in the forest, } \\
\text { the resource unit (trees) are non-mobile. However, the growth and height of trees varies depending on the } \\
\text { different elevations in the forest }\end{array}$ \\
\hline $\begin{array}{l}\text { RU2 - growth and } \\
\text { replacement rate }\end{array}$ & $\begin{array}{l}\text { FORGECO } 2014 \text { (French national project), ARANGE } 2015 \\
\quad \text { (European project), Mathias et al. } 2015\end{array}$ & $\begin{array}{l}\text { Studies and dynamical models presented by both projects that analyze the replacement rates of trees, and } \\
\text { analyze the different growth of trees depending on the elevation. These references refer to high growth of } \\
\text { forest with respect to other forests in Europe }\end{array}$ \\
\hline RU4 - economic value & $\begin{array}{l}\text { Achard } 2011 \text { (Report), FORGECO } 2014 \text { (French national } \\
\text { project), ARANGE } 2015 \text { (European project) }\end{array}$ & $\begin{array}{c}\text { Studies the economic values of wood, deadwood, and fuel wood in the forest that are considered with a high } \\
\text { value in the French market }\end{array}$ \\
\hline $\begin{array}{l}\text { RU7 - spatial and } \\
\text { temporal distribution }\end{array}$ & $\begin{array}{c}\text { FORGECO } 2014 \text { (French national project), ARANGE } 2015 \\
\text { (European project) }\end{array}$ & $\begin{array}{c}\text { In the projects, specific importance is given to the spatial distribution of trees with focused study on } \\
\text { the effect of tree elevation on the growth of trees }\end{array}$ \\
\hline $\begin{array}{l}\text { A1 - number of relevant } \\
\text { actors }\end{array}$ & $\begin{array}{l}\text { Mountain areas in Europe } 2004 \text { (Reports), Tissot and } \\
\text { Yann } 2013 \text { (Report), FORGECO } 2014 \text { (French national } \\
\text { project), ARANGE } 2015 \text { (European project) }\end{array}$ & $\begin{array}{l}\text { The references discuss the importance of forest with an implication to the high touristic attractions in } \\
\text { the area, which allows for the development of the industry. Moreover, the forest has a lot wood production } \\
\text { actors in relative to its size }\end{array}$ \\
\hline A4 - location & $\begin{array}{c}\text { FORGECO } 2014 \text { (French national project), ARANGE } 2015 \\
\text { (European project) }\end{array}$ & $\begin{array}{c}\text { The close proximity of the forest to the agglomeration of Grenoble (a main city in France), has allowed for } \\
\text { the development of tourism as an important economic driver }\end{array}$ \\
\hline $\begin{array}{l}\text { A6 - norms/ social } \\
\text { capital }\end{array}$ & $\begin{array}{l}\text { Mountain areas in Europe } 2004 \text { (Reports), FORGECO } \\
2014 \text { (French national project), ARANGE } 2015 \\
\text { (European project) }\end{array}$ & $\begin{array}{c}\text { Conflicts arise in the forest with different objectives. The references reported two preferences of the } \\
\text { different actors: Tourism and nature conservation (with a preference of conservation), wood removal (with a } \\
\text { preference of harvest) }\end{array}$ \\
\hline $\begin{array}{l}\text { A7 - knowledge of SES/ } \\
\text { mental models }\end{array}$ & $\begin{array}{c}\text { FORGECO } 2014 \text { (French national project), ARANGE } 2015 \\
\text { (European project) }\end{array}$ & $\begin{array}{c}\text { The projects did many studies and conceptual approaches to anticipate and gather information about the } \\
\text { Quatre-Montagne forest SES }\end{array}$ \\
\hline I1 - harvesting I & $\begin{array}{l}\text { Achard } 2011 \text { (Report), FORGECO } 2014 \text { (French national } \\
\text { project), ARANGE } 2015 \text { (European project). }\end{array}$ & $\begin{array}{l}\text { On one hand, harvesting levels for wood production are reported to be high with respect to other European } \\
\text { mountain forest case studies approached with the project. On the other, the Quatre-Montagne forest is }\end{array}$ \\
\hline
\end{tabular}




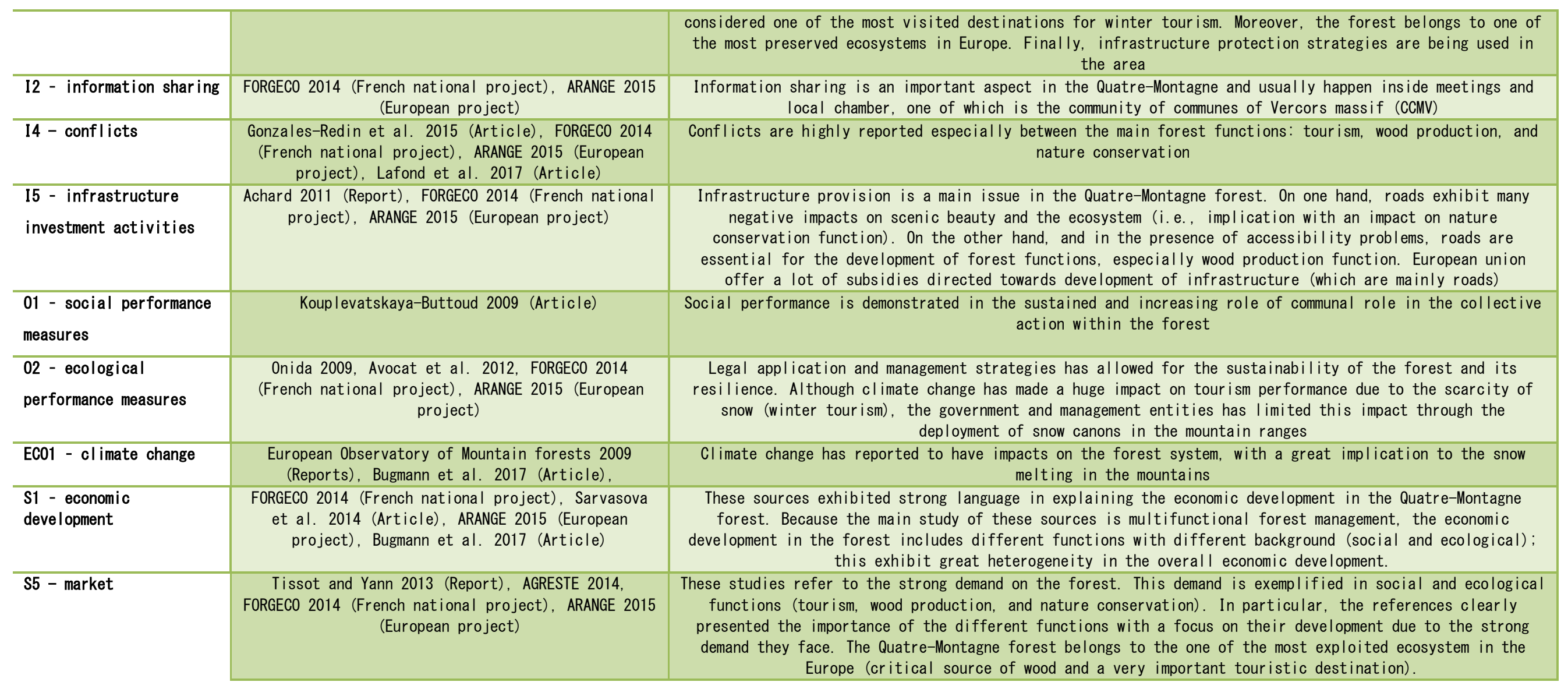

